\title{
RESEARCH
}

Open Access

\section{Histamine modulates microglia function}

\author{
Raquel Ferreira', Tiago Santos', Joana Gonçalves ${ }^{2,3}$, Graça Baltazar ${ }^{4}$, Lino Ferreira ${ }^{1,5}$, Fabienne Agasse \\ and Liliana Bernardino $0^{1,4,6^{*}}$
}

\begin{abstract}
Background: Histamine is commonly acknowledged as an inflammatory mediator in peripheral tissues, leaving its role in brain immune responses scarcely studied. Therefore, our aim was to uncover the cellular and molecular mechanisms elicited by this molecule and its receptors in microglia-induced inflammation by evaluating cell migration and inflammatory mediator release.

Methods: Firstly, we detected the expression of all known histamine receptor subtypes $\left(H_{1} R, H_{2} R, H_{3} R\right.$ and $\left.H_{4} R\right)$, using a murine microglial cell line and primary microglia cell cultures from rat cortex, by real-time PCR analysis, immunocytochemistry and Western blotting. Then, we evaluated the role of histamine in microglial cell motility by performing scratch wound assays. Results were further confirmed using murine cortex explants. Finally, interleukin1 beta (IL-1 $\beta$ ) and tumor necrosis factor-alpha (TNF-a) levels were evaluated by ELISA measurements to determine the role of histamine on the release of these inflammatory mediators.
\end{abstract}

Results: After $12 \mathrm{~h}$ of treatment, $100 \mu \mathrm{M}$ histamine and $10 \mu \mathrm{g} / \mathrm{ml}$ histamine-loaded poly (lactic-co-glycolic acid) microparticles significantly stimulated microglia motility via $\mathrm{H}_{4} \mathrm{R}$ activation. In addition, migration involves a5 $\beta 1$ integrins, and p38 and Akt signaling pathways. Migration of microglial cells was also enhanced in the presence of lipopolysaccharide (LPS, $100 \mathrm{ng} / \mathrm{ml})$, used as a positive control. Importantly, histamine inhibited LPS-stimulated migration via $\mathrm{H}_{4} \mathrm{R}$ activation. Histamine or $\mathrm{H}_{4} \mathrm{R}$ agonist also inhibited LPS-induced IL-1 $\beta$ release in both N9 microglia cell line and hippocampal organotypic slice cultures.

Conclusions: To our knowledge, we are the first to show a dual role of histamine in the modulation of microglial inflammatory responses. Altogether, our data suggest that histamine per se triggers microglia motility, whereas histamine impedes LPS-induced microglia migration and IL-1 $\beta$ release. This last datum assigns a new putative antiinflammatory role for histamine, acting via $\mathrm{H}_{4} \mathrm{R}$ to restrain exacerbated microglial responses under inflammatory challenge, which could have strong repercussions in the treatment of CNS disorders accompanied by microgliaderived inflammation.

Keywords: Histamine, Microglia, Inflammation, Histamine 4 receptor, Migration

\section{Background}

Microglial cells play a pivotal role in the immune surveillance of the central nervous system (CNS) by avidly surveying the brain parenchyma in search of infection, injury, or other sources of pathology $[1,2]$. In this sense, microglial cells become activated and migrate to the injury site in order to fully develop a concerted immune response, involving the release of both trophic and pro-inflammatory

\footnotetext{
* Correspondence: libernardino@gmail.com

${ }^{1}$ CNC - Center for Neuroscience and Cell Biology, University of Coimbra,

Coimbra, Portugal

${ }^{4}$ CICS-UBI - Health Sciences Research Center, University of Beira Interior,

Covilhã, Portugal

Full list of author information is available at the end of the article
}

factors [1]. The study of the classical components that constitute the microglia response in the inflammatory process has been copiously supported by the use of lipopolysaccharide (LPS), a gram-negative cell wall component. LPS binds to the CD14/TLR4/MD2 receptor complex, located on the cell membrane, triggering classical microglial responses such as proliferation, migration, phagocytosis and release of inflammatory mediators $[3,4]$. Histamine is an endogenous biogenic amine mostly stored in the granules of mast cells and basophils that readily release their content upon stimulation [5]. Other sources of histamine include histaminergic neurons, gastric enterochromaffin-like cells, leukocytes and platelets, to name a

\section{Ciomed Central}


few. Moreover, in the CNS, histamine is released by microglial cells [6]. Histamine exerts its various functions through the activation of four distinct subtypes of G-protein coupled receptors: $\mathrm{H}_{1}$ receptor $\left(\mathrm{H}_{1} \mathrm{R}\right), \mathrm{H}_{2}$ receptor $\left(\mathrm{H}_{2} \mathrm{R}\right), \mathrm{H}_{3}$ receptor $\left(\mathrm{H}_{3} \mathrm{R}\right)$ and $\mathrm{H}_{4}$ receptor $\left(\mathrm{H}_{4} \mathrm{R}\right)$ [7]. Their actions range mainly from the modulation of the allergic reaction $\left(\mathrm{H}_{1} \mathrm{R}\right)$, regulation of heart and gastric acid secretion $\left(\mathrm{H}_{2} \mathrm{R}\right)$ to neurotransmitter release $\left(\mathrm{H}_{3} \mathrm{R}\right) . \mathrm{H}_{4} \mathrm{R}$ is mainly expressed by cells of the immune system (e.g., Band T-lymphocytes, dendritic cells, eosinophils, fibroblasts, mast cells, monocytes, natural killer cells and neutrophils), and its expression is modulated by an inflammatory context [8]. At the moment, $\mathrm{H}_{4} \mathrm{R}$ is primarily known for its chemotactic effect on mast cells and eosinophils (reviewed by [9]).

In our study, we showed for the first time that all known histamine receptors are expressed in microglial cells. We also showed that histamine per se stimulates microglia motility. However, and most interestingly, in an LPS-induced inflammatory context, histamine has an inhibitory action in microglia migration and in the release of interleukin-1beta (IL-1 $\beta)$. In summary, we uncovered a novel dual role for histamine in the regulation of neuroinflammation mediated by microglia activity by modulating cell recruitment and the release of pro-inflammatory cytokines, such as IL-1 $\beta$ and tumor necrosis factor-alpha (TNF)- $\alpha$.

\section{Methods}

All experiments were performed in accordance with European Union (2010/63/EU) guidelines for the care and use of laboratory animals. All efforts were made to minimize animal suffering and the number of animals used.

\section{Cell line culture}

The murine N9 microglia cell line (a kind gift from Prof. Claudia Verderio, CNR Institute of Neuroscience, Cellular and Molecular Pharmacology, Milan, Italy) was grown as previously described [10]. Cells were plated at a density of $2 \times 10^{4}$ cells per well in 24-well trays (immunocytochemistry), $5 \times 10^{4}$ cells per well in 12-well trays (scratch wound assays) or plated at a density of $5 \times 10^{5}$ cells per well in 6 well trays (for the remaining experiments). Cell treatments included the following incubation setup: histamine dihydrochloride (1-100 $\mu \mathrm{M}$, Sigma), LPS (100 ng/ml, Sigma), $\alpha 5 \beta 1$ blocking antibody $(10 \mu \mathrm{g} / \mathrm{ml}$, Millipore Corp., Bedford, MA, USA), $\mathrm{H}_{1}$ receptor antagonist, 2-((2-(dimethylamino)ethyl)(p-methoxybenzyl)amino)-pyridine maleate (mepyramine maleate, $1 \mu \mathrm{M}$ ), $\mathrm{H}_{2}$ receptor antagonist, $\mathrm{N}$ cyano-N'-methyl-N"-[2-[(5-methyl-1 H-imidazol-4-yl)methyl]thio] ethyl]guanidine (cimetidine, $5 \mu \mathrm{M}), \mathrm{H}_{3}$ receptor antagonist 3-amino-N-[2-(1 H-imidazol-4-yl)ethyl]propanamide ditrifluoroacetate (carcinine ditrifluoroacetate, 5 $\mu \mathrm{M}), \mathrm{H}_{4}$ receptor antagonist, 1-[(5-chloro-1 H-indol-2-yl) carbonyl]-4-methylpiperazine (JNJ7777120, $5 \mu \mathrm{M}$ ) and $\mathrm{H}_{4}$ receptor agonist, 5-(2-aminoethyl)-4-methylimidazole dihydrochloride (4-methylhistamine dihydrochloride, 20 $\mu \mathrm{M}$ ) (all from Tocris, Ballwin, MO, USA) for $3 \mathrm{~h}$ (receptor expression evaluation), $6 \mathrm{~h}$ (cytokine release) or $12 \mathrm{~h}$ (migration studies). Wortmanin (50 nM, Alomone Labs Ltd., Jerusalem, Israel), p38 inhibitor SB239063 (20 $\mu$ M, Sigma) and all histamine receptor antagonists/agonists were added 40 min prior to cell treatment.

\section{Primary microglia cell cultures from cortex}

Mixed glial cultures from the cortex were prepared as previously described by Saura and colleagues (2003) [11]. Briefly, neonatal Wistar rats (P2-4) were killed, and the brains were placed in ice-cold $0.15 \mathrm{M}$ sterile PBS. After removal of the meninges, cortex explants were digested in cysteine solution (1.9 $\mathrm{mM} \mathrm{CaCl}_{2}, 1.3 \mathrm{mM}$ cysteine) and $\mathrm{H} \& \mathrm{~B}$ solution $(116 \mathrm{mM} \mathrm{NaCl}, 5.4 \mathrm{mM} \mathrm{KCl}, 26 \mathrm{mM}$ $\mathrm{NaHCO}_{3}, 12 \mathrm{mM} \mathrm{NaH} \mathrm{PO}_{4} \cdot \mathrm{H}_{2} \mathrm{O}, 1 \mathrm{mM} \mathrm{MgSO} 4.7 \mathrm{H}_{2} \mathrm{O}, 0.5$ mM EDTA, $25 \mathrm{mM}$ glicose, $\mathrm{pH}$ 7.3) supplemented with 20 $\mathrm{U} / \mathrm{ml}$ papain and $0.001 \%$ phenol red at $37^{\circ} \mathrm{C}$ for $4 \mathrm{~min}$, under constant agitation. Then, the tissue was rinsed with high glucose Dulbecco's modified Eagle's medium (DMEM, Invitrogen, Paisley, UK) supplemented with $10 \%$ fetal bovine serum (FBS), $100 \mathrm{U} / \mathrm{ml}$ penicillin and $100 \mu \mathrm{g} / \mathrm{ml}$ streptomycin. After mechanical dissociation, cells were pelleted by centrifugation (3 min, 405× g; 3K18C Bioblock Scientific; Sigma Laboratory Centrifuges) and suspended in DMEM. The cells were then plated into 12-well cell culture plates at a density of $0.087 \times 10^{6}$ cells per well. The cultures were kept at $37^{\circ} \mathrm{C}$ in a $5 \% \mathrm{CO}_{2}$ and $95 \%$ air atmosphere, and the cell medium was changed every 7 days. On day 20-21, a mild trypsinization (trypsin dilution 1:3 in DMEM without FBS) was done for $40 \mathrm{~min}$ at $37^{\circ} \mathrm{C}$ to remove astrocytes. The resultant adherent microglial cells were washed twice with DMEM and kept at $37^{\circ} \mathrm{C}$ in a $5 \% \mathrm{CO}_{2}$ and $95 \%$ air atmosphere for a further 5 days before RT-PCR and Western blot experiments. More than $98 \%$ of the cells in culture were immunopositive for the microglia marker CD11b.

\section{Brain cortex explants}

Adult wild-type (WT) C57BL6 mice were used for the study of cell motility in cortex explants. Briefly, mice were killed, and the brains were placed in Hank's balanced salt solution (HBSS), supplemented with 100 $\mathrm{U} / \mathrm{ml}$ penicillin and $100 \mu \mathrm{g} / \mathrm{ml}$ streptomycin (all from Invitrogen). After removal of the meninges, cortex explants (spanning all cortical layers) were dissected from $400-\mu$ m-thick coronal sections using a tissue chopper under a stereoscopic microscope and placed individually over poly-D-lysine-coated $(0.1 \mathrm{mg} / \mathrm{ml})$ glass coverslips in 12-well cell culture plates. Explants were allowed to adhere for $4 \mathrm{~h}$ before the medium was replaced to Opti-MEM (50\%), heat-inactivated horse 
serum (25\%) and HBSS (25\%), supplemented with Dglucose to a final concentration of $25 \mathrm{mM}$ and $100 \mathrm{U} / \mathrm{ml}$ penicillin and $100 \mu \mathrm{g} / \mathrm{ml}$ streptomycin (all from Invitrogen). The motility assay occurred for $24 \mathrm{~h}$, after medium replacement, at $5 \% \mathrm{CO}_{2}$ and $95 \%$ atmospheric air at $37^{\circ}$ $\mathrm{C}$, before fixation.

Results are expressed as the number of CD11b-positive cells, denoting microglial and/or CNS macrophages, that migrated from the explants within a $300-\mu \mathrm{m}$ radius from the explant edge and normalized per explant area (number of CD11b-positive cells $/ \mathrm{mm}^{2}$ ). Cell migration was only evaluated in explants with an area ranging from 1 to $1.5 \mathrm{~mm}^{2}$. Explant images were acquired using MetaFluor Software (Universal Imaging, Downingtown, PA, USA), and the explant area and radius were analyzed with NIH ImageJ Software.

\section{Organotypic hippocampal slice cultures}

Briefly, 7-day-old C57BL6 WT mice were killed by decapitation, their brains removed under sterile conditions, and the hippocampi isolated and cut in 350- $\mu \mathrm{m}$ coronal sections using a McIlwain tissue chopper. Individual slices were placed in ice-cold Gey's balanced salt solution (Biological Industries, Israel) supplemented with 25 mM D-glucose (Merck, Darmstadt, Germany), 100 U/ml penicillin and $100 \mu \mathrm{g} / \mathrm{ml}$ streptomycin, before being placed on porous insert membranes (Millipore Corp.). Six slices were put onto each membrane, and the inserts were transferred to a six-well culture tray (Corning Costar, Corning, NY, USA). Each well contained $1 \mathrm{ml}$ culture medium, composed of 50\% Opti-minimal essential medium, 25\% heat-inactivated horse serum, and $25 \%$ HBSS supplemented with $25 \mathrm{mM}$ D-glucose, $50 \mathrm{U} / \mathrm{ml}$ penicillin and $50 \mu \mathrm{g} / \mathrm{ml}$ streptomycin (all from Invitrogen). Slices were allowed to grow for 2 weeks before the ELISA experiments.

\section{Real-time polymerase chain reaction analysis of histamine receptors expression}

Total RNA was isolated from the N9 murine microglial cell line, from primary microglia cell cultures from the cortex and from hippocampal extracts (positive control) according to the illustra RNAspin Mini RNA Isolation Kit manufacturer's instructions (GE Healthcare Life Sciences, Buckinghamshire, UK). Precipitated RNA was resuspended in $20 \mu \mathrm{l}$ of diethylpyrocarbonate (DEPC)treated water and quantified by optical density (NanoDrop 2000, ThermoScientific, Waltham, MA, USA). For cDNA synthesis, $2 \mu \mathrm{g}$ of total RNA was mixed with 2.5 $\mu \mathrm{M}$ anchored-oligo-p $(\mathrm{dT}) 18$ primers, $1 \times \mathrm{PCR}$ reaction buffer, $20 \mathrm{U}$ RNase inhibitor, dNTPs (1 mM each) and 10 U AMV Reverse Transcriptase in a $20-\mu$ l final volume (Roche Molecular Biochemicals). The reaction was performed at $55^{\circ} \mathrm{C}$ for $30 \mathrm{~min}$ and stopped by $85^{\circ} \mathrm{C}$ for a 5 - min step. For gene expression analysis, $1 \mu$ l of sample cDNA was added to $10 \mu \mathrm{l}$ EvaGreen Supermix (BioRad, Hercules, CA, USA), and the final concentration of each primer was $10 \mu \mathrm{M}$ in $20 \mu \mathrm{l}$ total reaction volume. The thermocycling reaction was initiated with activation of Taq DNA polymerase by heating at $94^{\circ} \mathrm{C}$ for $3 \mathrm{~min}$, followed by 30 cycles of a 15 -s denaturation step at $94^{\circ} \mathrm{C}$, and a $30 \mathrm{~s}$ annealing and elongation step at $57^{\circ} \mathrm{C}$ for all sets of primers. For housekeeping gene hypoxanthine phosphoribosyltransferase 1 (HPRT-1), primer sets were obtained from selected QuantiTect Primer Assays (Qiagen, Austin, Texas). Fluorescence was measured after the extension step by the iQ5 Multicolor Real-Time PCR Detection System (BioRad). After the thermocycling reaction, the melting step was performed with slow heating, starting at $55^{\circ} \mathrm{C}$ and with a rate of $0.5^{\circ} \mathrm{C}$ per $10 \mathrm{~s}$, up to $95^{\circ} \mathrm{C}$, with continuous measurement of fluorescence, allowing detection of possible nonspecific products. The assay included a non-template control (sample was substituted by sterile water), a negative transcriptase reaction sample and a standard curve (in 10-fold steps) of DNA for assessing the efficiency of each set of primers. All reactions were run in duplicates. $\mathrm{Ct}$ values were measured in the exponential phase and were set at the same fluorescence value in each run performed. $\Delta \mathrm{Ct}$ was calculated by subtracting each $\mathrm{Ct}$ sample from in-plate $\mathrm{Ct}$ of the housekeeping reference gene HPRT-1. A smaller $\Delta \mathrm{Ct}$ value represents higher gene expression. Data analysis was performed with Biorad iQ5 software (BioRad). The PCR products were subjected to electrophoresis in a $1 \%$ agarose gel stained with ethidium bromide. Digital photographs were taken in a Versa-Doc Imaging System (Model 3000, BioRad).

Primer sequences: $\mathrm{H}_{1} \mathrm{R}$, forward primer 5'-GGG CTC AAA GGC CAA TGA C-3' and reverse primer 5'-TCC GCC GGC AAG TAC TCA-3' (74 bp); $\mathrm{H}_{2} \mathrm{R}$, forward primer 5'-CTG GCT GTC AGC TTG AAT CG-3' and reverse primer 5'-GCT GCC AGG GAC ACA ATG A-3' (65 bp); $\mathrm{H}_{3} \mathrm{R}$, forward primer 5'-CTT CTC TCT CCC AAG ACG ATC TG-3' and reverse primer 5'-GGC TCC GGG ATT AAG GAA GA-3' (65 bp); $\mathrm{H}_{4} \mathrm{R}$, forward primer 5'-GCT ACG ATC GAT ACC AGT CA-3' and reverse primer 5'-AAG AAA GCC AGT ATC CAA ACA G-3' (109 bp) (synthesized by Eurofins MWG Operon, Ebersberg, Germany).

\section{Preparation and characterization of PLGA microparticles}

The single emulsion technique was used to prepare microparticles of approximately $2 \mu \mathrm{m}$ in diameter. PLGA (resomer $752 \mathrm{H}$ ) (100 mg; Boehringer Mannheim; Mannheim) was dissolved in $2.5 \mathrm{ml}$ of a solvent mixture (1:4 methylene chloride: trifluoroethanol), and $5 \mathrm{mg}$ histamine was added. This solution was added to a stirred chilled polyvinyl alcohol (PVA) solution [100 ml, 5\% (w/ 
v)]. The resulting suspension was stirred for $3 \mathrm{~h}$, washed with distilled water and finally freeze-dried. The morphology and diameter of PLGA particles were evaluated by scanning electron microscopy according to our previous reports [12]. Release experiments in $0.15 \mathrm{M} \mathrm{PBS}$ at $37^{\circ} \mathrm{C}$ were performed in order to evaluate the release profile of histamine over 30 days and to assess the loading efficiency of the microparticles. The loading capacity of PLGA microparticles was approximately $5.3 \mu \mathrm{g}$ of histamine per $\mathrm{mg}$ of microparticles. Approximately $1 \mu \mathrm{g}$ of histamine was released per mg of microparticles over 4 days [13]. Blank microparticles, i.e., without histamine, were also prepared to test the effect of the microparticle formulation per se [13].

\section{Motility assay}

Before N9 microglial cell seeding, two parallel lines were carved on the underside of each well with a scalpel. These lines served as a guidance axis together with the line provided by the scratch wound. The cell monolayer was approximately 95\% confluent before the migration assay took place. One hour before performing the wound, medium was replaced by serum-free medium to ensure no proliferation occurred during experiments. The wound was made by a perpendicular scratch made with a P10 pipette tip (Gilson S.A.S., Villiers-le-Bel, France). After N9 microglial cell treatment, images were taken with an inverted Axiovert 200 microscope (Carl Zeiss, Göttingen, Germany), with a $5 \times$ objective and a CoolSNAP digital camera (Roper Scientific, Tucson, AZ, USA). Differential interference contrast (DIC) images were acquired using MetaFluor Software (Universal Imaging, Downingtown, PA, USA) and analyzed with NIH ImageJ Software. For the N9 microglia cell line, cell motility was determined by counting the number of cells that migrated towards the middle of the wound within a $12-\mathrm{h}$ period of treatment. The protocol was adapted from Valster and colleagues (2005) [14].

\section{Enzyme-linked immunosorbent assay for IL-1 $\beta$}

Cells were plated and treated as described above (see section Cell line culture). Cells were left at room temperature (RT) for $5 \mathrm{~min}$ in lysis buffer [137 $\mathrm{mM}$ $\mathrm{NaCl}, 20 \mathrm{mM}$ Tris-HCl, 1\% Triton X-100, 10\% glycerol, $1 \mathrm{mM}$ phenylmethylsulfonyl fluoride (PMSF), $10 \mu \mathrm{g} / \mathrm{ml}$ aprotinin, $1 \mu \mathrm{g} / \mathrm{ml}$ leupeptin, $0.5 \mathrm{mM}$ sodium orthovanadate (all from Sigma), pH 8.0]. Total protein concentration was determined by the bicinchoninic acid method $(\mathrm{BCA})$, and samples were stored at $-80^{\circ} \mathrm{C}$. For the quantification of IL- $1 \beta$ protein levels, a mouse IL-1 $\beta$ ELISA kit was used following the manufacturer's instructions (eBioscience, San Diego, CA). For that purpose, Microtiter plates (MaxiSorp, Nunc A/S, Roskilde, Denmark) were used. Optical density was recorded at 450 and 570 $\mathrm{nm}$ (values later subtracted from those obtained with $450 \mathrm{~nm}$ ) in an ELISA plate (SPECTRA max 384 Plus, Molecular Devices).

\section{Enzyme-linked immunosorbent assay for TNF-a}

Cells were plated and treated as described above (see section Cell line culture). After cell lysis and protein quantification, as described above (see section Enzymelinked immunosorbent assay for IL-1 $\beta$ ), a mouse TNF- $\alpha$ ELISA kit was used according to the manufacturer's instructions (eBioscience). Optical density was recorded at 450 and $620 \mathrm{~nm}$ (values later subtracted from those obtained with $450 \mathrm{~nm}$ ) in an ELISA plate (SPECTRA max 384 Plus, Molecular Devices).

\section{Western blotting}

For total extracts, cells were incubated with lysis cocktail solution [137 mM NaCl, $20 \mathrm{mM}$ Tris- $\mathrm{HCl}, 1 \%$ Triton X$100,10 \%$ glycerol, $1 \mathrm{mM}$ phenylmethylsulfonyl fluoride, $10 \mu \mathrm{g} / \mathrm{ml}$ aprotinin, $1 \mu \mathrm{g} / \mathrm{ml}$ leupeptin, $0.5 \mathrm{mM}$ sodium vanadate (all from Sigma), $\mathrm{pH}$ 8.0]. Samples were centrifuged for $20 \mathrm{~min}$ at $4,300 \mathrm{~g}$ at $4{ }^{\circ} \mathrm{C}$, and the supernatant collected.

The total amount of protein was quantified using the BCA assay. Afterwards, 50- $\mu$ g samples were loaded onto $12 \%$ acrylamide/bisacrilamide gels (BioRad). Proteins were separated by SDS-PAGE using a bicine/SDS (Sigma) electrophoresis buffer $(\mathrm{pH} 8.3)$ and then transferred to PVDF membranes (Millipore) on the following conditions: 300 $\mathrm{mA}, 90 \mathrm{~min}$ at $4^{\circ} \mathrm{C}$ in a solution containing $10 \mathrm{mM}$ CAPS and 20\% methanol, pH 11.0). Membranes were blocked in Tris-buffer saline containing 5\% BSA and $0.1 \%$ Tween $^{\circledR}$ 20 (Sigma) for $1 \mathrm{~h}$, at RT, and then incubated overnight at $4{ }^{\circ} \mathrm{C}$ with the primary antibody solution diluted in $0.1 \%$ TBS-Tween, 5\% BSA. The following primary antibodies were used: goat polyclonal anti- $\mathrm{H}_{4}$ receptor $(1: 5,000$, Santa Cruz Biotechnology, Inc., Santa Cruz, CA, USA) and mouse monoclonal anti-GAPDH (1:10,000, Millipore) (all from Cell Signaling). After rinsing with TBS-T, membranes were incubated for $1 \mathrm{~h}$ at RT with an alkaline phosphatase-linked secondary antibody anti-goat or antimouse IgG 1:10,000, in 5\% BSA, 0.1\% Tween ${ }^{\circledR} 20$ (Sigma) and 1\% TBS-T (GE Healthcare UK Limited, Buckinghamshire, UK). Protein immunoreactive bands were visualized in a Versa-Doc Imaging System (Model 3000, BioRad), after incubation of the membrane with ECF reagent (GE Healthcare UK Limited) for 5 min.

\section{Immunocytochemistry}

Cells were fixed with $4 \%$ PFA, and unspecific binding was prevented by incubating cells in a $3 \%$ BSA and $0.1 \%$ Triton X-100 solution for $30 \mathrm{~min}$ at RT. Cells were kept overnight at $4^{\circ} \mathrm{C}$ in blocking solution with the primary antibodies, then washed with $0.15 \mathrm{M}$ PBS and incubated 
for $2 \mathrm{~h}$ at $\mathrm{RT}$ with the corresponding secondary antibody. Antibodies were used as listed: goat polyclonal anti- $\mathrm{H}_{4}$ receptor $(1: 5,000$, Santa Cruz Biotechnology, Inc., CA, USA), rat monoclonal anti-CD11b (1:1,000, AbD Serotec, Oxfordshire, UK) and rat monoclonal $\alpha 5 \beta 1$ antibody $(10 \mu \mathrm{g} / \mathrm{ml}$, Millipore) in $0.1 \%$ Triton X100, 0.3\% BSA solution; Alexa Fluor 594 donkey antigoat and Alexa Fluor 488 goat anti-rat (all 1:200 in PBS, from Molecular Probes, Eugene, OR, USA). For nuclear labeling, cell preparations were counterstained with Hoechst $33342(2 \mu \mathrm{g} / \mathrm{ml})$ (Molecular Probes) in $0.15 \mathrm{M}$ PBS for 5 min at RT and mounted in Dakocytomation fluorescent medium (Dakocytomation Inc.). Fluorescent images were acquired using a confocal microscope with a Plan-ApoChromat $63 \times / 1.40$ oil objective (N9 microglial cells) or Plan-ApoChromat $40 \times / 1.3$ oil objective (cortex explants) (LSM 510 Meta, Carl Zeiss).

\section{Data analysis}

Statistical analysis was performed using GraphPad Prism 5.0 (GraphPad Software, San Diego, CA). Statistical significance was considered relevant for $p$ values $<0.05$ using one-way analysis of variance followed by Bonferroni's post hoc test for comparison among experimental settings and Dunnett's post hoc test for comparison with control conditions. Data were presented as means \pm standard error of mean (SEM). For the N9 microglia cell line motility assay, four images per experimental condition were acquired. For cortex explants, a series of images around the whole specimen were taken to count every cell within a $300-\mu \mathrm{m}$ radius from the explants. Every experimental condition was tested in three sets of independent experiments, unless stated otherwise, and performed in duplicates.

\section{Results}

\section{Microglial cells express histamine $\mathrm{H}_{4}$ receptor}

In this work, we studied the role of histamine in microglial-induced inflammatory responses, and for that purpose, we used complementary approaches using a murine microglia cell line, primary microglia cultures from the cortex, hippocampal organotypic slice cultures and cortex explants. We previously validated the use of the N9 cell line in the study of microglial responses by showing that neuropeptide $Y$ dampens both LPS- and IL-1 $\beta$-stimulated cell migration, phagocytosis and the release of potent pro-inflammatory mediators $[10,15,16]$.

Firstly, we performed real-time polymerase chain reaction (qPCR) to identify the expression of all known histamine receptors. In that sense, we amplified cDNA coding for $\mathrm{H}_{1} \mathrm{R}, \mathrm{H}_{2} \mathrm{R}, \mathrm{H}_{3} \mathrm{R}$ and $\mathrm{H}_{4} \mathrm{R}$, and normalized the relative expression of each gene against a previously selected housekeeping gene, hypoxanthine phosphoribosyltransferase 1 (HPRT-1) [17]. We found that N9 microglial cells expressed low basal levels of $\mathrm{H}_{1} \mathrm{R}, \mathrm{H}_{2} \mathrm{R}$ and $\mathrm{H}_{3} \mathrm{R}$, whereas $\mathrm{H}_{4} \mathrm{R}$ appeared to be more abundantly expressed $\left(\Delta \mathrm{CtH}_{1} \mathrm{R}=13.4 \pm 0.7 ; \Delta \mathrm{CtH}_{2} \mathrm{R}=15.0 \pm 1.3 ; \Delta \mathrm{CtH}_{3} \mathrm{R}=16.4\right.$ $\pm 2.3 ; \Delta \mathrm{CtH}_{4} \mathrm{R}=13.0 \pm 0.3 ; \mathrm{n}=3-4$ ) (Figure 1A). A smaller $\Delta \mathrm{Ct}$ value represents higher gene expression. Negative controls showed no amplification (data not shown). $\mathrm{H}_{4} \mathrm{R}$ is mainly expressed by cells of the immune system. Since its role in the CNS has been poorly discussed, and to our knowledge, we are the first to report $\mathrm{H}_{4} \mathrm{R}$ expression by microglial cells, we then focused our study on this receptor $[8,18]$. Accordingly, we performed Western blotting to determine whether differences regarding the pattern of receptor expression existed in an inflammatory context. Interestingly, LPS challenge $(100 \mathrm{ng} / \mathrm{ml}$, for $12 \mathrm{~h})$ did not alter $\mathrm{H}_{4} \mathrm{R}$ protein expression by $\mathrm{N} 9$ microglial cells (Figure 1B). For both experimental approaches, primary microglia cultures obtained from the cortex $(\mathrm{Cx})$ were used as positive controls. Furthermore, for qPCR analysis we also used whole hippocampus cDNA as a positive control [19] (data not shown). Then, we confirmed by immunocytochemistry that both N9 microglial cells (top panel) and cortex primary microglia cell cultures (bottom panel) expressed $\mathrm{H}_{4} \mathrm{R}$ (in red), in a similar fashion, in control conditions and under LPS challenge (Figure 1C). As a positive control, coronal brain slices were used for $\mathrm{H}_{4} \mathrm{R}$ positive immunodetection on the hippocampus [19] (data not shown). To visualize cell morphology we labeled the alpha chain of $\alpha_{M} \beta_{2}$-integrin, CD11b (in green), a wellknown surface marker for microglia and leukocytes, whose over-expression is associated to microglial and/or CNS macrophage activation [20].

\section{Histamine induces microglia motility through $\mathrm{H}_{4} \mathrm{R}$ activation}

To evaluate the effect of histamine on microglia motility, we determined the number of N9 microglial cells that migrated in vitro across a scratch wound (Figures 2, 3, 4, 5). Accordingly, we performed a dose-response curve to assess a functionally relevant concentration of histamine (Figure 2A). Microglial cells were treated for $12 \mathrm{~h}$ with concentrations of histamine ranging from 1 to $100 \mu \mathrm{M}$, and we observed that only $100 \mu \mathrm{M}$ histamine significantly induced cell motility $\left(\right.$ mean $_{\mathrm{CTR}}=101.9 \pm 4.9$ cells; mean $_{\mathrm{HIS} 100 \mu \mathrm{M}}=174.4 \pm 5.9$ cells; $\left.p<0.001, n=13-20\right)$. At this concentration, histamine did not interfere with microglia cell death or proliferation (data not shown). We also developed histamine-loaded poly (lactic-coglycolic acid) (PLGA) microparticles in order to promote a more efficient and controlled delivery of histamine in the cell culture medium. Histamine in solution can be rapidly degraded, posing difficulties in the delivery of therapeutic doses in an in vivo approach. We were the first to develop histamine-loaded microparticles as a powerful strategy to overcome these limitations by ensuring local and continuous (up to 30 days) 


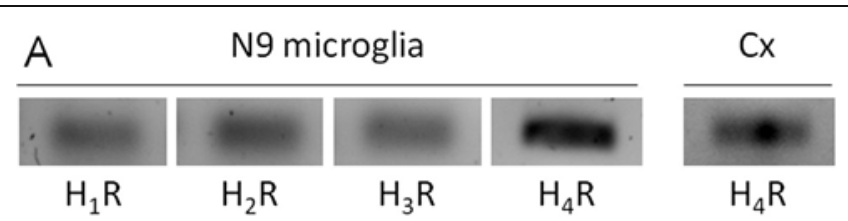

B

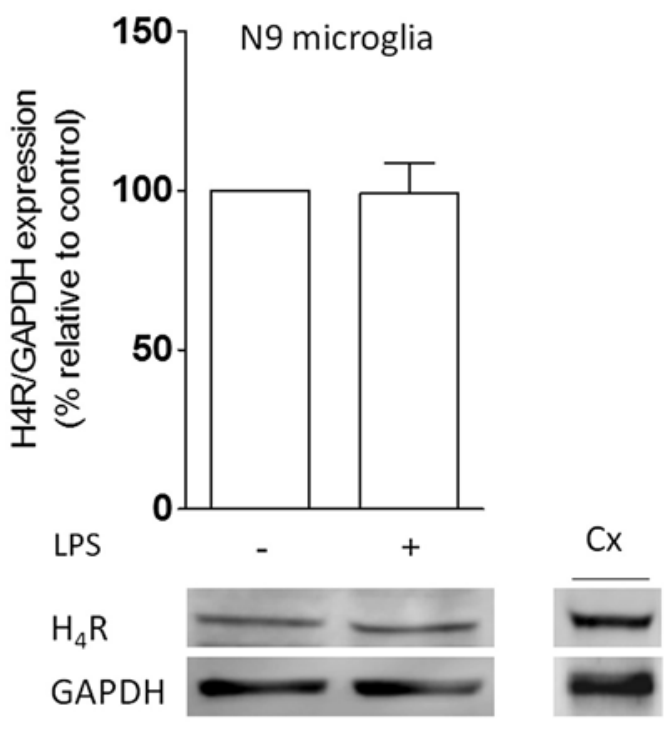

C

N9 microglia cell line

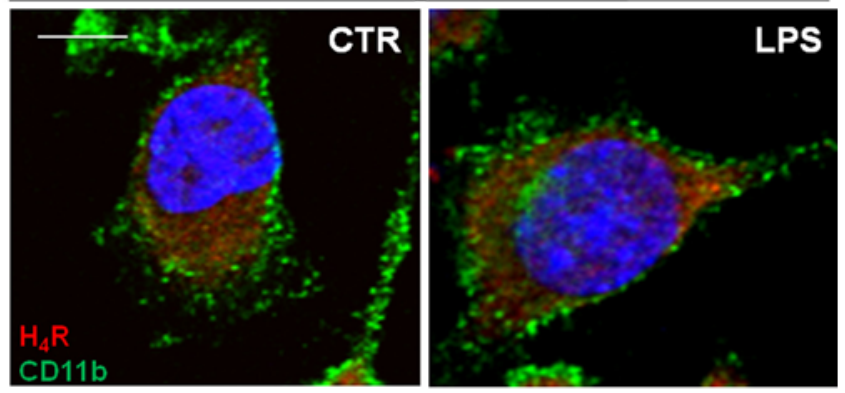

Primary cortex microglia

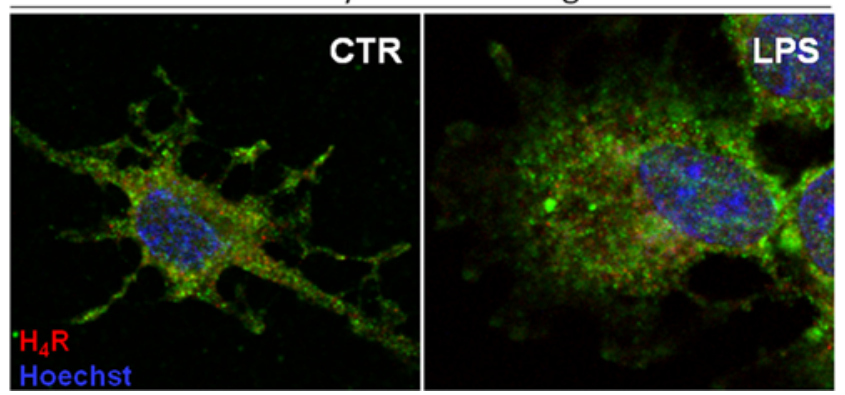

Figure 1 Microglial cells express histamine receptors. (A) Histamine receptor expression analysis by real-time PCR showed that microglial cells constitutively express all known histamine receptors - $\mathrm{H}_{1} \mathrm{R}(74 \mathrm{bp}), \mathrm{H}_{2} \mathrm{R}(65 \mathrm{bp}), \mathrm{H}_{3} \mathrm{R}(65 \mathrm{bp})$ and $\mathrm{H}_{4} \mathrm{R}$ (109 bp). (B) LPS stimulation (100 ng/ml) did not alter the expression of $\mathrm{H}_{4} \mathrm{R}$, quantified by Western blotting. Data are expressed as percentage of control $(n=3-4)$. A representative blot is shown below the graph $\left(\mathrm{H}_{4} \mathrm{R}, 44 \mathrm{kDa}\right.$; GAPDH, $37 \mathrm{kDa}$ ). In both experimental paradigms, primary microglia cultures from the cortex (Cx) were used as a positive control. For qPCR, whole hippocampal cDNA was used as an additional positive control (data not shown). (C) N9 microglial cells (top panel) and primary cortical microglia cultures (bottom pane) expressed $\mathrm{H}_{4} \mathrm{R}$ (in red) under control conditions and upon LPS challenge (100 ng/ml). Cells were stained for morphology marker CD1 1b (in green) and Hoechst 33342 (nuclei in blue). Scale bar, $10 \mu \mathrm{m}$. 
(See figure on the previous column)

Figure 2 Histamine induces microglia migration via $\mathrm{H}_{4}$ receptor activation. (A) Within the range of concentrations tested, only 100 $\mu \mathrm{M}$ histamine significantly induced microglia motility. Moreover, 10 $\mu \mathrm{g} / \mathrm{ml}$ histamine-loaded PLGA microparticles ( $\mu \mathrm{P}, 10 \mu \mathrm{g} / \mathrm{ml}$ ) mimicked the effect of $100 \mu \mathrm{M}$ histamine, whereas blank microparticles did not enhance motility. (B) Histamine-induced motility was inhibited in the presence of $\mathrm{H}_{4} \mathrm{R}$ antagonist (Ant $\mathrm{H}_{4} \mathrm{R}$ : JNJ7777120, $5 \mu \mathrm{M})$. Accordingly, $\mathrm{H}_{4} \mathrm{R}$ agonist application $\left(\mathrm{Ag} \mathrm{H}_{4} \mathrm{R}\right.$ : 4methylhistamine dihydrochloride, $20 \mu \mathrm{M}$ ) resembled histamine treatment. The involvement of other receptors was excluded since the application of their respective antagonists did not interfere with the migration-inducing effect of histamine $\left[\mathrm{H}_{1} \mathrm{R}\right.$ antagonist (mepyramine maleate), $1 \mu \mathrm{M} ; \mathrm{H}_{2} \mathrm{R}$ antagonist (cimetidine), $5 \mu \mathrm{M} ; \mathrm{H}_{3} \mathrm{R}$ antagonist (carcinine ditrifluoroacetate), $5 \mu \mathrm{M})$ ]. (C) Representative photomicrographs depict the migratory effect induced by histamine and $\mathrm{H}_{4} \mathrm{R}$ agonist in $\mathrm{N} 9$ microglia cell line, an effect abolished in the presence of the $\mathrm{H}_{4} \mathrm{R}$ antagonist. Data are expressed as mean \pm SEM $(n=3-20)$ and as mean total number of cells migrating across the scratch wound $\left({ }^{*} p<0.05\right.$, ${ }^{* *} p<0.01,{ }^{* *} p<0.001$, using Bonferroni's multiple comparison test).

extracellular release of histamine [13]. In previous work by our group, histamine-loaded PLGA microparticles were shown to efficiently promote neurogenesis without any cytotoxic effect [13]. Accordingly, $10 \mu \mathrm{g} / \mathrm{ml}$ histamine-loaded microparticles significantly promoted cell motility, whereas blank (void formulation) particles had no effect $\left(\right.$ mean $_{\mathrm{uP} 10 \mu \mathrm{g} / \mathrm{ml}}=166.4 \pm 19.7$ cells; meanblank $=107.7 \pm 3.2$ cells; $p<0.01, n=3-4)$. LPS challenge $(100 \mathrm{ng} / \mathrm{ml})$ was used as a positive control $\left(\operatorname{mean}_{\text {LPS }}=\right.$ $167.0 \pm 11.2$ cells; $p<0.001, n=13$ ) (Figure $2 \mathrm{~A}$ ). To uncover which histamine receptor was involved, we treated N9 microglial cells with histamine $(100 \mu \mathrm{M})$ together with an antagonist for each receptor individually (data not shown), and only $\mathrm{H}_{4} \mathrm{R}$ antagonist (JNJ7777120, $5 \mu \mathrm{M}$ ) significantly reduced histamineinduced migration $\left(\right.$ mean $_{\mathrm{HIS}+\mathrm{H} 4 \mathrm{R} \text { ant }}=93.5 \pm 11.1$ cells; $p<0.001, n=4)$. Moreover, the simultaneous blockade of other receptors $\left[\mathrm{H}_{1} \mathrm{R}\right.$ antagonist, mepyramine maleate $(1 \mu \mathrm{M}), \mathrm{H}_{2} \mathrm{R}$ antagonist, cimetidine $(5 \mu \mathrm{M})$ and $\mathrm{H}_{3} \mathrm{R}$ antagonist, carcinine ditrifluoroacetate $(5 \mu \mathrm{M})]$ did not abolish histamine-induced migration $\left(\right.$ mean $_{\mathrm{HIS}+\mathrm{AntH} 1,2,3 \mathrm{R}}=$ $142.6 \pm 12.8$ cells; $p<0.05, n=4)$. Noteworthily, application of an $\mathrm{H}_{4} \mathrm{R}$ agonist (4-methylhistamine dihydrochloride, $20 \mu \mathrm{M})$ mimicked the effect induced by histamine per se $\left(\right.$ mean $_{\mathrm{H} 4 \mathrm{R}}$ ag $=159.2 \pm 9.3$ cells; $p<0.05, n=8$ ) (Figure $2 \mathrm{~B})$. Representative digital images depict the migratory effect induced by histamine through the activation of $\mathrm{H}_{4} \mathrm{R}$ (Figure 2C). These data suggest that histamine per se induced microglia motility via $\mathrm{H}_{4} \mathrm{R}$ activation.

\section{Histamine-induced migration requires a $5 \beta 1$ integrin signaling}

An important feature for cell motility to occur is the presence of membrane integrins that promote the

Figure 2 (See legend on next column) 


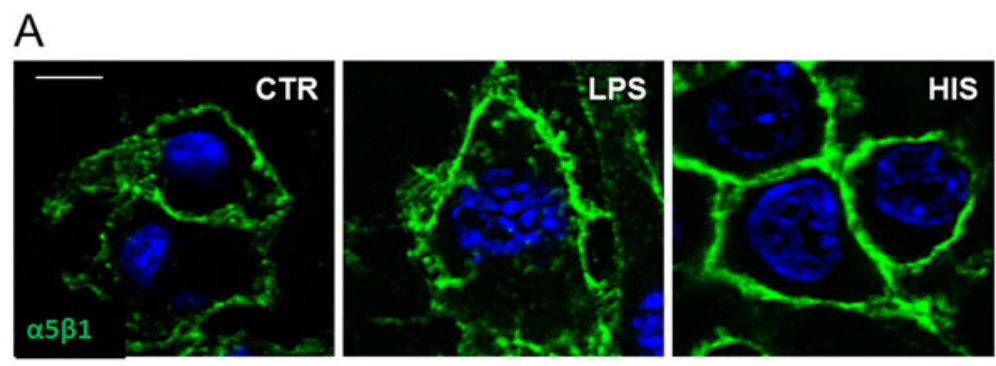

B

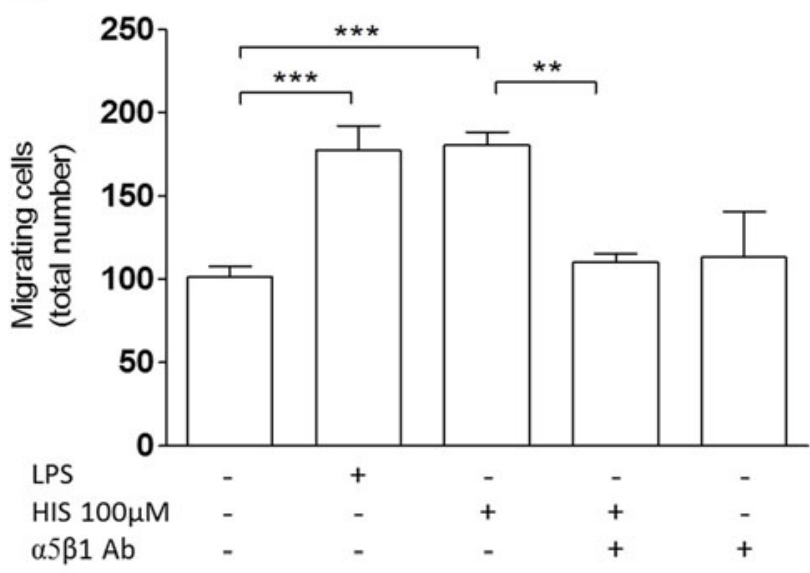

C
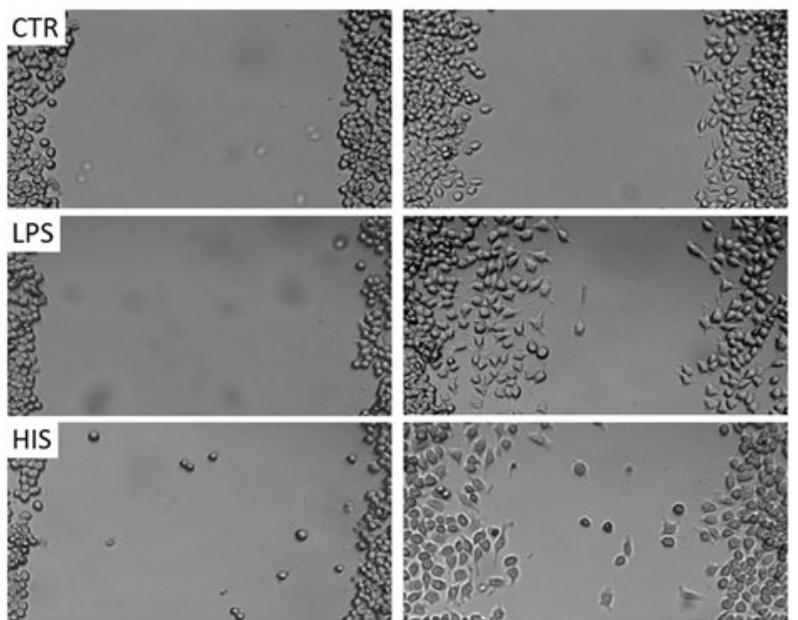

$\mathrm{HIS}+\alpha 5 \beta 1 \mathrm{Ab}$
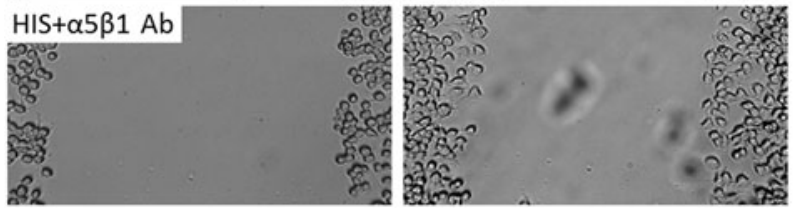

Figure 3 Histamine-induced motility requires a5 $\beta 1$ integrin involvement. (A) a5 $\beta 1$ integrin is expressed (in green) in the presence of LPS $(100 \mathrm{ng} / \mathrm{ml})$ or histamine treatment $(100 \mu \mathrm{M})$ observed by confocal microscopy. Nuclear labeling (in blue) was obtained with Hoechst 33342 staining. (B) Blockade of a5 $\beta 1$ integrin ( $55 \beta 1$ Ab neutralizing antibody: $10 \mu \mathrm{g} / \mathrm{ml}$ ) impeded histamine-stimulated motility. (C) Representative photomicrographs depict the migratory effect induced by histamine, which was abolished when a5 $\beta 1$ integrin was blocked. Data are expressed as mean \pm SEM $(n=3-20)$ and as mean total number of cells migrating across the scratch wound $\left({ }^{* *} p<0.01,{ }^{* * *} p<0.001\right.$, using Bonferroni's multiple comparison test). Scale bar, $10 \mu \mathrm{m}$. 


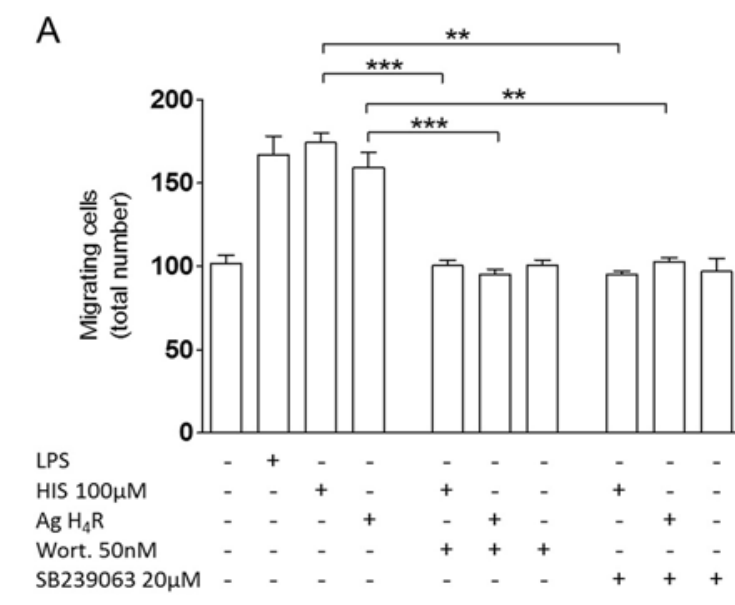

\section{B}
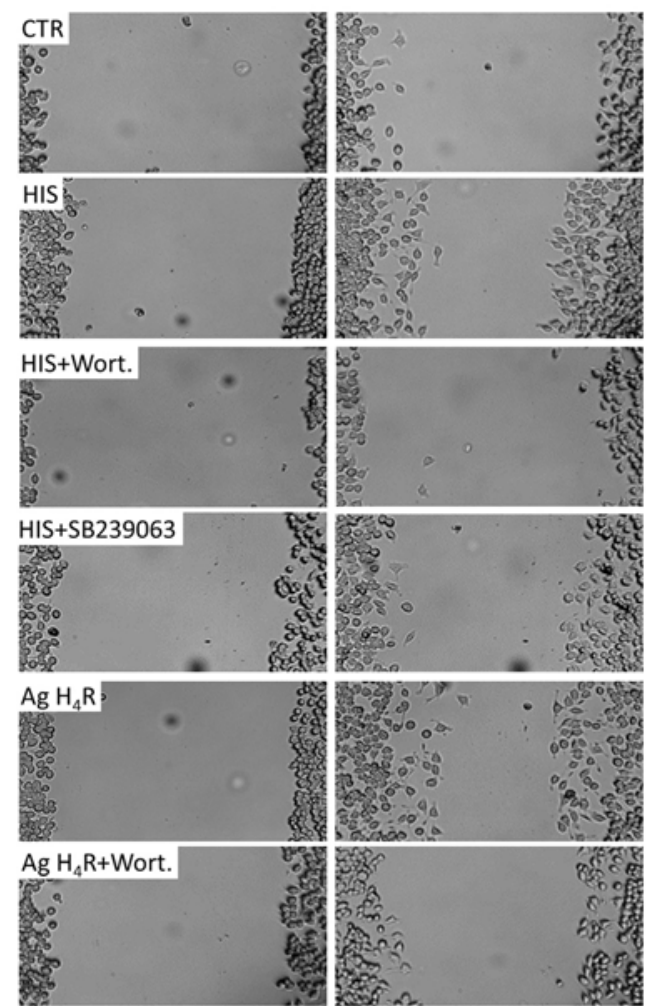

$\mathrm{Ag} \mathrm{H}_{4} \mathrm{R}+\mathrm{SB} 239063$
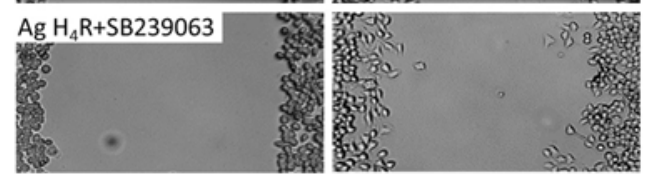

Figure 4 Histamine-induced migration requires p38 and Akt signaling pathways. (A) In scratch wound assays, both histamineand $\mathrm{H}_{4} \mathrm{R}$ agonist-induced migration were inhibited in the presence of Akt inhibitor, wortmannin (50 nM) or p38 inhibitor, SB239063 (20 $\mu \mathrm{M})$. (B) Representative photomicrographs depict the inhibitory effect on migration induced by p38 and Akt signaling blockade. Data are expressed as mean \pm SEM $(n=3-20)$ and as mean total number of cells migrating across the scratch wound $\left({ }^{* *} p<0.01\right.$, ${ }^{* * *} p<0.001$, using Bonferroni's multiple comparison test). formation of adhesion sites to the substrate [21,22]. For this purpose, we immunolabeled alpha5/beta1 ( $\alpha 5 \beta 1)$ integrin and observed that upon LPS challenge or histamine treatment, N9 microglial cells displayed a robust $\alpha 5 \beta 1$ integrin expression (in green) on their cell surface (Figure 3). Accordingly, when we blocked this integrin by adding $10 \mathrm{ug} / \mathrm{ml}$ of the anti- $\alpha 5 \beta 1$ integrinneutralizing antibody, histamine-induced motility was compromised $\left(\right.$ mean $_{\mathrm{HIS100 \mu M}}=174.4 \pm 5.9$ cells; mean $_{\mathrm{HIS}}$ ${ }_{+\alpha 5 \beta 1}=110.3 \pm 5.3$ cells; $p<0.01, n=3-13$ ) (Figure 3B). The neutralizing antibody against $\alpha 5 \beta 1$ alone did not have any effect. Representative digital images depict the histamine-induced migratory effect promoted by $\alpha 5 \beta 1$ integrin (Figure $3 \mathrm{C}$ ). Other integrins, such as the integrin $\alpha 6$ subunit, which forms a heterodimer with integrin $\beta 1$ or $\beta 4$, and recognizes laminin as a ligand, was not involved in histamine-induced motility, as tested using a neutralizing antibody directed against $\alpha 6$ subunit (data not shown). Therefore, the integrin $\alpha 5 \beta 1$ is involved in the pro-migratory effect induced by histamine in the N9 cell line.

\section{Histamine-induced migration requires p38 and AKT signaling pathways}

We also addressed which signaling pathways could be involved in our migration model (Figure 4). Given that we have previously demonstrated the involvement of p38 MAPK signaling in LPS-induced migration [16] and that the PI3K/Akt pathway has been correlated with $\mathrm{H}_{4} \mathrm{R}$-stimulated mast cell chemotaxis [23] and with microglia migration [24,25], we evaluated the effect of SB239063 (p38 inhibitor) and wortmannin (Akt inhibitor) on histamine-induced motility. Accordingly, in the presence of $50 \mathrm{nM}$ wortmannin, both histamine- and $\mathrm{H}_{4} \mathrm{R}$ agonist-induced migration were abolished $\left(\right.$ mean $_{\text {HIS+wort }}=100.4 \pm 3.4$ cells; mean $_{\mathrm{H} 4 \mathrm{R}}$ ag+wort $=95.1 \pm 3.1$ cells; $p<0.001, \quad n=3$ ) (Figure 4A). Similarly, pre-treatment with $20 \mu \mathrm{M}$ SB239063 inhibited both histamine- and $\mathrm{H}_{4} \mathrm{R}$ agonistinduced migration $\left(\right.$ mean $_{\mathrm{HIS}+\mathrm{SB} 239063}=95.0 \pm 2.1$ cells; mean $_{\mathrm{H} 4 \mathrm{R}}$ ag+SB239063 $=102.8 \pm 2.4$ cells; $p<0.01, n=3$ ) (Figure 4A). Neither wortmannin nor SB239063 alone modulated microglia migration. These data suggest that the p38 and AKT signaling pathways can be involved in the migration induced by histamine or $\mathrm{H}_{4} \mathrm{R}$ agonist per se.

\section{Histamine $\mathrm{H}_{4}$ receptor activation modulates LPS-induced microglia motility}

We then decided to evaluate the role of histamine in an inflammatory context and found that, upon LPS and histamine co-administration, migration induced by LPS alone was significantly inhibited $\left(\right.$ mean $_{\text {LPS }}=167.0 \pm 11.2$ cells, mean $_{\text {HIS }+ \text { LPS }}=112.0 \pm 5.7$ cells; $p<0.001, n=7-13$ ) 


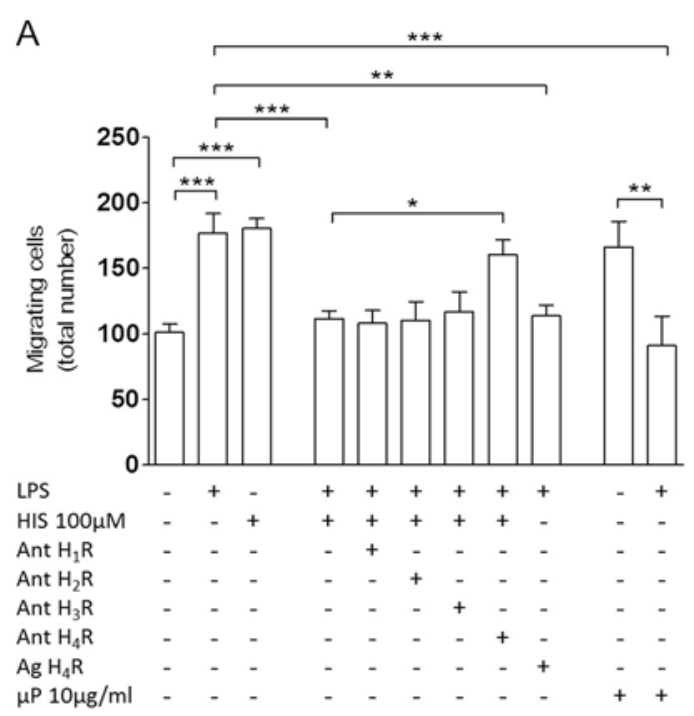

\section{B}
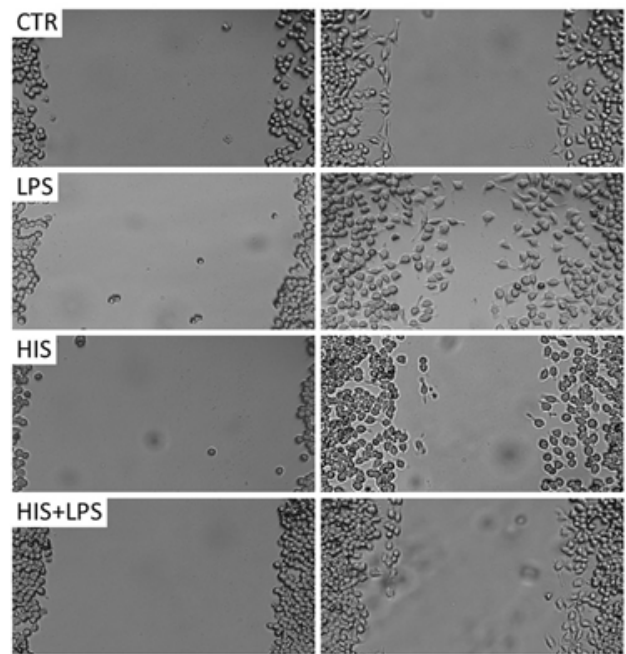

HIS+LPS+Ant $\mathrm{H}_{4} \mathrm{R}$
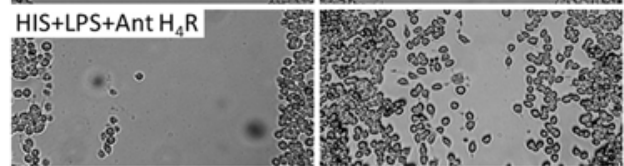

LPS $+\mathrm{Ag} \mathrm{H}_{4} \mathrm{R}$

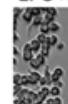

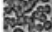

Figure $\mathbf{5}$ LPS-induced motility is inhibited by histamine via $\mathrm{H}_{\mathbf{4}}$ receptor activation. (A) Upon an inflammatory challenge triggered by LPS (100 ng/ml), $100 \mu \mathrm{M}$ histamine inhibited migration, an effect involving $\mathrm{H}_{4} \mathrm{R}$ activation. In the presence of histamine, only when $\mathrm{H}_{4} \mathrm{R}$ was blocked (Ant $\mathrm{H}_{4} \mathrm{R}$ : JNJ7777120, $5 \mu \mathrm{M}$ ), LPS-induced

migration was restored. (B) Representative photomicrographs depict the inhibitory effect of histamine on LPS-induced motility upon $\mathrm{H}_{4} \mathrm{R}$ activation. Data are expressed as mean \pm SEM $(n=3-20)$ and as mean total number of cells migrating across the scratch wound $\left({ }^{*} p<0.05\right.$, ${ }^{* *} p<0.01,{ }^{* * *} p<0.001$, using Bonferroni's multiple comparison test).
(Figure 5A). The co-administration of histamine together with LPS did not induce cell death or proliferation (data not shown). Moreover, cells treated with both histamine and LPS and in the presence of the $\mathrm{H}_{4} \mathrm{R}$ antagonist displayed a motility rate similar to LPS alonetreated microglia. The inhibition of LPS-induced migration by histamine is mediated by $\mathrm{H}_{4} \mathrm{R}$ activation, since in the presence of $H 4 R$ antagonist, the stimulatory effect on migration is restored $\left(\right.$ mean $_{\mathrm{HIS}+\mathrm{LPS}+\mathrm{H} 4 \mathrm{R} \text { ant }}=160.8 \pm$ 11.2 cells; $n=3-15 ; p<0.05, n=4)$. Likewise, application of $\mathrm{H}_{4} \mathrm{R}$ agonist significantly reduced LPS-induced motility $\left(\right.$ mean $_{\mathrm{H} 4 \mathrm{R}} \mathrm{Ag}+\mathrm{LPS}=114.0 \pm 7.7$ cells; $\left.p<0.01, n=4\right)$. Accordingly, none of the other receptor antagonists interfered with the ability of histamine to reduce LPS-stimulated migration (Figure 5A). Notably, histamine-loaded microparticles $(10 \mu \mathrm{g} / \mathrm{ml})$ also inhibited LPS-induced motility $\left(\mathrm{mean}_{\mathrm{uP} 10 \mu \mathrm{g} / \mathrm{ml}}\right.$ + LPS $=91.3 \pm 22.5$ cells; $p<0.001, n=4)$. Representative digital images depict the inhibitory effect of histamine on LPS-induced motility through $\mathrm{H}_{4} \mathrm{R}$ activation (Figure 5B).

We later explored the role of histamine in a more complex biological model that closely resembles the physiological environment by using murine cortex explants (Figure 6). Similarly to the in vitro cell line model, we observed that histamine alone, acting through $\mathrm{H}_{4} \mathrm{R}$, or LPS alone stimulated migration of microglia/ CNS invading macrophages $\left(\right.$ mean $_{\mathrm{CTR}}=8.9 \pm 2.8$ cells; mean $_{\mathrm{HIS}}=24.0 \pm 6.5$ cells; mean $_{\mathrm{H} 4 \mathrm{R}} \mathrm{ag}=36.5 \pm 9.1$ cells; mean $_{\mathrm{LPS}}=34.1 \pm 7.4$ cells; $\left.p<0.05, \quad p<0.01, \quad n=5-9\right)$. Moreover, exposure of explants to histamine or $\mathrm{H}_{4} \mathrm{R}$ agonist, together with LPS, reduced migration, whereas blockade of $\mathrm{H}_{4} \mathrm{R}$, in this context, restored migration to levels similar to the ones observed in LPS-treated cells $\left(\right.$ mean $_{\mathrm{HIS}+\mathrm{LPS}}=14.2 \pm 4.5$ cells; mean $_{\mathrm{H} 4 \mathrm{R}} \mathrm{ag}+\mathrm{LPS}=13.2 \pm$ 5.6 cells; mean $_{\mathrm{HIS}+\mathrm{H} 4 \mathrm{R} \text { ant }+\mathrm{LPS}}=27.0 \pm 3.9$ cells; $p<0.05$, $n=5-8$ ) (Figure 6B). Altogether, these data suggest that histamine, in the presence of a robust inflammatory milieu induced by LPS, acting via $\mathrm{H}_{4} \mathrm{R}$ activation, drastically reduced microglia migration.

Application of the $\mathrm{H}_{4} \mathrm{R}$ antagonist restored LPS-stimulated motility in the presence of histamine. Data are expressed as mean \pm SEM $(n=4-9)$ and as total number of migrating CD11b-positive cells per explant area (number of migrating CD11b-positive cells $\left./ \mathrm{mm}^{2}\right)(" p<0.05$, using Bonferroni's mu comparison test). Scale bar, $10 \mu \mathrm{m}$.

\section{Histamine modulates proinflammatory cytokine release}

Another key feature of inflammation is the release of signaling proinflammatory cytokines, such as IL-1 $\beta$ and tumor necrosis factor-alpha (TNF- $\alpha$ ), by microglial cells [26].

Using a quantitative method, ELISA, we analyzed the release of IL-1 $\beta$ and TNF- $\alpha$ by N9 microglial 

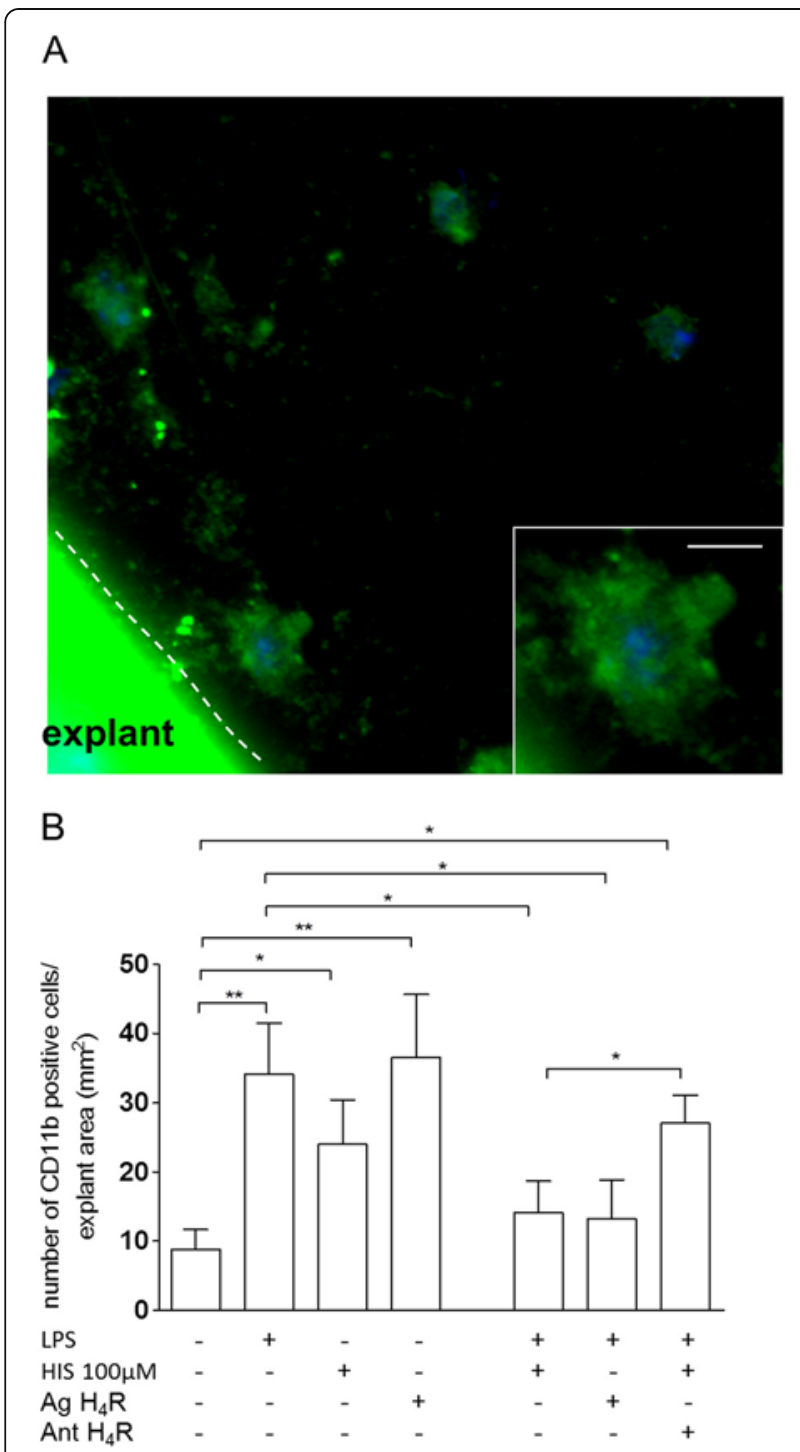

Figure 6 Histamine promotes microglia/CNS macrophage migration via $\mathrm{H}_{4}$ receptor activation in cortex explants. (A) Representative confocal microscopy micrographs depict CD11bpositive cells (in green) migrating from and within the explant, in the presence of LPS treatment (100 $\mathrm{ng} / \mathrm{ml})$. Inset highlights microglia/ CNS macrophage morphology. (B) LPS and histamine individually increased motility, while co-administration abolished this effect. Likewise, in the presence of $\mathrm{H}_{4} \mathrm{R}$ agonist, LPS-induced motility was also decreased.

cell line (Figure 7A) and by hippocampal organotypic slice cultures (Figure 7B). Regarding the cell line, we observed that in the presence of LPS, there was a significant release of biologically active IL-1 $\beta$ (mature form) to the culture media $\left(\right.$ mean $_{\text {CTR }}=138.5 \pm 28.3$ $\mathrm{pg}, \quad \operatorname{mean}_{\mathrm{LPS}}=410.5 \pm 96.2 \mathrm{pg} ; \quad p<0.01, \quad n=4-7$ ) (Figure 7A, left graph). LPS-induced release of IL-1 $\beta$ was abolished when cells were simultaneously treated with histamine and LPS $\left(\operatorname{mean}_{\mathrm{HIS}+\mathrm{LPS}}=119.0 \pm 28.0\right.$ pg; $p<0.01, n=3$ ). Application of the $\mathrm{H}_{4} \mathrm{R}$ agonist (20 $\mu \mathrm{M})$ together with LPS mimicked the inhibitory effect of histamine, whereas blockade of $\mathrm{H}_{4} \mathrm{R}(5 \mu \mathrm{M})$ abolished histamine-induced inhibition of IL- $1 \beta$ release $\left(\right.$ mean $_{\mathrm{H} 4 \mathrm{R} \text { ag }}=72.1 \pm 43.8 \mathrm{pg}, \operatorname{mean}_{\mathrm{H} 4 \mathrm{R} \text { ag }+\mathrm{LPS}}=101.5 \pm$ $64.4 \mathrm{pg}, \operatorname{mean}_{\mathrm{HIS}+\mathrm{H} 4 \mathrm{R}}$ ant+LPS $=534.1 \pm 119.4 \mathrm{pg} ; p$ $<0.01, p<0.001, n=3)$. Noteworthily, application of histamine-loaded microparticles $(10 \mu \mathrm{g} / \mathrm{ml})$ had the same inhibitory effect of histamine under an inflammatory challenge $\left(\right.$ mean $_{\mathrm{uP} 10 \mu \mathrm{g} / \mathrm{ml}+\mathrm{LPS}}=142.7 \pm 29.7$ cells; $p<0.05, n=3$ ).

Interestingly, the inhibitory effect of histamine was not observed over LPS-induced TNF- $\alpha$ release (Figure 7A, right graph). LPS challenge stimulated TNF- $\alpha$ release; however, histamine or histamine-loaded microparticles had no effect on the release of this cytokine induced by LPS (Figure 7A, right graph).

In hippocampal organotypic slice cultures, LPS significantly increased IL- $1 \beta$ release $\left(\operatorname{mean}_{\mathrm{CTR}}=17.6 \pm 5.5 \mathrm{pg} /\right.$ $\left.\mathrm{ml} ; \operatorname{mean}_{\mathrm{LPS}}=200.7 \pm 37.4 \mathrm{pg} / \mathrm{ml} ; p<0.001, \quad n=8-11\right)$ (Figure 7B, left graph). However, in the presence of histamine or $\mathrm{H}_{4} \mathrm{R}$ agonist, LPS-induced release was markedly reduced $\left(\right.$ mean $_{\mathrm{HIS}+\mathrm{LPS}}=41.3 \pm 4.2 \mathrm{pg} / \mathrm{ml} ;$ mean $_{\mathrm{H} 4 \mathrm{R} \text { ag }}$ +LPS $=37.1 \pm 1.7 \mathrm{pg} / \mathrm{ml} ; p<0.001, n=4)$. Further enhancing the involvement of $\mathrm{H}_{4} \mathrm{R}$ on this effect, the use of a $\mathrm{H}_{4} \mathrm{R}$ antagonist partially restored the full LPS-induced IL-1 $\beta$ release $\left(\right.$ mean $_{\mathrm{HIS}+\mathrm{H} 4 \mathrm{R} \text { ant }+\mathrm{LPS}}=68.0 \pm 9.4 \mathrm{pg} / \mathrm{ml} ; p$ $<0.05, n=4$ ) (Figure 7B, left graph). Histamine-loaded microparticles did not decrease LPS-induced IL-1 $\beta$ release in this experimental model (data not shown). Since using microwell inserts, where organotypic slices are placed, does not allow an efficient interaction with microparticles (particles will tend to deposit on the bottom of the well), we did not pursue their application further. In accordance with the previous data shown in the N9 cell line, in hippocampal organotypic slice cultures, TNF- $\alpha$ release remained unaffected by histamine treatment (Figure 7B, right graph). LPS challenge significantly increased TNF- $\alpha$ release, but histamine did not reduce this effect.

\section{Discussion}

Historically, histamine has been mainly addressed as an important mediator of allergic reactions occurring in peripheral tissues. In recent years, with the discovery of new histamine receptors and new sources of histamine in the brain, it has become clear that histamine has an increasingly defined role in the CNS. Regarding brain function, histamine is involved in the modulation of biological rhythms, sensory and motor systems, thermoregulation, learning and memory, mood and feeding behavior [27]. However, little is known about the role of histamine in brain inflammation. Most importantly, although microglial cells have been identified as a source of histamine, there 


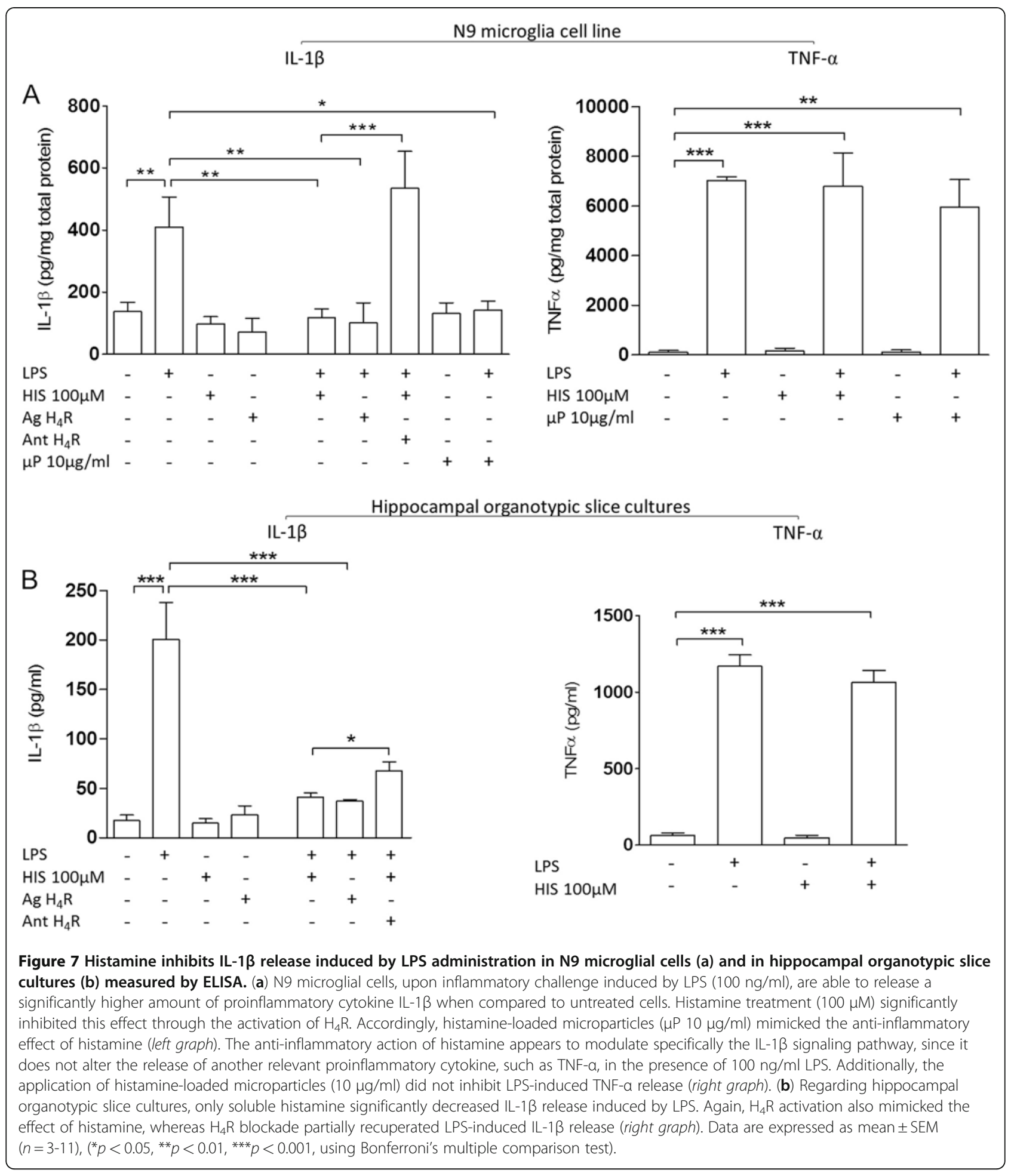

are few reports on how the activity/function of these cells is modulated by this amine. As such, given the active immunoregulatory role of microglial cells in the brain parenchyma, we sought to decipher the modulatory actions of histamine over classical microglial responses, such as migration and inflammatory mediator release. In our study, we demonstrated that histamine, acting via $\mathrm{H}_{4} \mathrm{R}$, showed dual effects on microglia-induced responses. Histamine per se stimulated microglia motility, as compared with untreated controls, and this migratory effect requires the expression of $\alpha 5 \beta 1$ integrin and occurs with the involvement of p38 MAPK and Akt signaling pathways. This 
effect suggests that histamine alone may function similarly to an inflammatory mediator, although it does not change the release of the cytokines IL- $1 \beta$ and TNF- $\alpha$.

Importantly, it should be noted that microglial activation, a common feature of most brain pathologies, can be coupled to either a pro- or anti-inflammatory profile and exhibits several functionally distinct phenotypes. Moreover, since microglia continually surveys their microenvironment, migration cannot be univocally associated with a proinflammatory setting (as reviewed by [28]).

Of note, given an inflammatory context, such as our experimental paradigm mimicked by the administration of LPS, histamine inhibited microglial migration to levels similar to control cultures. Moreover, histamine also inhibited LPS-induced IL- $1 \beta$ release, although it did not interfere with LPS-induced TNF- $\alpha$ release. Therefore, in the presence of a strong and robust inflammatory context, histamine may repress microglia-mediated migration and counteract additional tissue damage.

To our knowledge, we are the first to report the detection of $\mathrm{H}_{4} \mathrm{R}$ expression in both primary microglia cultures from the cerebral cortex and in a microglia cell line. To evaluate the role of histamine on microglial cell migration, we adopted two experimental approaches, with different degrees of complexity: scratch wound assays and murine cortex explants. The use of scratch wound assays allowed a complete pharmacological study of the dual effect of histamine on cell migration, while cortex explants offered a more physiological environment. Using these models, we observed that $100 \mu \mathrm{M}$ histamine and $10 \mu \mathrm{g} / \mathrm{ml}$ histamine-loaded microparticles stimulated microglia migration. Histamine-loaded microparticles can promote a more efficient and controlled delivery of histamine, without cytotoxic effects [13].

Moreover, we determined that this pro-migratory effect induced by histamine was occurring through $\mathrm{H}_{4} \mathrm{R}$ activation. $\mathrm{H}_{4} \mathrm{R}$ is expressed mainly by immune cells whose receptor activation modulates migration or cell recruitment, calcium mobilization, cell differentiation and cytokine production, depending on the cell type. In particular, $\mathrm{H}_{4} \mathrm{R}$ induces chemotaxis of eosinophils, mast cells, and dendritic and $\mathrm{T}$ cells, while reducing monocyte recruitment (reviewed in [8]). In response to injury or inflammation, microglial cells become activated and migrate in a process that requires actin polymerization and the upregulation of adhesion molecule CD11b, among other adhesion molecules. In eosinophils, low concentrations of histamine (below $10 \mathrm{mM}$ ) lead to actin polymerization and significant $\mathrm{CD} 11 \mathrm{~b}$ upregulation, an effect blocked by thioperamide, an $\mathrm{H}_{3} \mathrm{R} / \mathrm{H}_{4} \mathrm{R}$ antagonist [29]. Another key component required for cell movement is the expression of integrins, a diverse family of migration-inducing receptors, which are responsible for cell-cell, cell-extracellular matrix (ECM) and cell-pathogen interactions [22,30]. Integrins are heterodimeric complexes composed by different combinations of alpha $(\alpha)$ /beta $(\beta)$ subunits, which later define receptor specificity. $\beta 1$ integrin is the most widespread $\beta$ subunit, and it is involved in microglia chemotaxis and proliferation [31]. In our work, we showed that $\alpha 5 \beta 1$ integrin blockade impaired histamine-induced migration, suggesting that this heterodimer is required for microglia migration. We should note that scratch wound assays were performed without any substrate covering the bottom of the wells. However, microglial cells are able to secrete fibronectin, an $\alpha 5 \beta 1$ ligand (assessed by Western blotting; data not shown), therefore enabling cell movement. We further disclosed the mechanisms involved in histamine-induced migration by evaluating the participation of p38 mitogen-activated protein kinase and Akt signaling pathways. We have previously demonstrated that LPS-induced microglia migration requires p38 phosphorylation [16]. In addition, $\mathrm{H}_{4} \mathrm{R}$ activation may rapidly and transiently induce the phosphorylation of ERK, MEK and Akt in other immune cell types [23-25]. Nevertheless, using selective inhibitors of these pathways, SB239063 (p38 inhibitor) and wortmannin (Akt inhibitor), we blocked histamine-induced migration, suggesting that these pathways are required for cell movement.

To the best of our knowledge, there is only one report suggesting crosstalk between alpha5beta1 integrin expression and p38/Akt pathways in cell migration. $\alpha 5 \beta 1$ and $\alpha v \beta 3$ integrin-mediated human umbilical vein endothelial cell (HUVEC) adhesion to fibronectin or vitronectin activates integrin-dependent intracellular signaling cascades, including PI3K/AKT, ERK, p38 and JNK, which subsequently lead to the stimulation of AP-1-dependent MMP-9 expression in HUVECs. However, the authors only showed that blocking antibodies targeting $\alpha 5 \beta 1$ and $\alpha v \beta 3$ integrins abolished fibronectin-stimulated c-Jun phosphorylation, while blocking antibodies targeting $\beta 1$ and $\alpha v \beta 3$ reduced vitronectin-stimulated MMP-9 activity [32]. Nevertheless, several studies showed some evidence of crosstalk among integrins/MAPKs/Akt in cell invasion, although invasion and migration are different processes since the latter does not necessarily require invasion to occur [33-37].

There are several indications of $\mathrm{H}_{4} \mathrm{R}$ involvement in inflammatory disorders, including allergy, asthma, chronic pruritus and rheumatoid arthritis, to name a few [8]. In our study, we showed that histamine had a dual effect on microglial cell migration. In a physiological context, histamine, histamine-loaded microparticles or $\mathrm{H}_{4} \mathrm{R}$ agonist application induced migration, whereas, in the presence of LPS, these compounds had an inhibitory effect. Our results were further validated using murine cortex explants, which provided a more physiological environment to disclose the effect of histamine in cell migration. Accordingly, we 
observed the same inhibitory action of histamine in the presence of an inflammatory challenge using this model. In that sense, $\mathrm{H}_{4} \mathrm{R}$ may have therapeutic value in the treatment of inflammatory conditions or symptoms, although histamine has been mainly regarded as a proinflammatory agent. In fact, Smits and colleagues have designed and evaluated the role of several $\mathrm{H}_{4} \mathrm{R}$ ligands. The group found that 6,7-dichloro-3-(4-methylpiperazin-1-yl)quinoxalin-2(1 H)one and 2-benzyl-3-(4-methyl-piperazin-1-yl)quinoxaline (two $\mathrm{H}_{4} \mathrm{R}$ agonists) displayed significant in vivo anti-inflammatory activity in the rat carrageenan-induced paw edema model [38], validating the use of $\mathrm{H}_{4} \mathrm{R}$ ligands as anti-inflammatory agents in vivo. Furthermore, application of $\mathrm{H}_{4} \mathrm{R}$ agonists has provided a reduction of asthma-like symptoms due to enhanced migration of CD4+/CD25+/FoxP3+ T regulatory cells (Tregs) to the inflammation site, where these accumulated cells release the anti-inflammatory cytokine IL-10 [39]. Additionally, Osna and colleagues reported that histamine upregulates IL-10 production by murine splenocytes in a dose-dependent manner; however, this effect was reversed by both H1- and H2-receptor antagonists [40]. In addition, $\mathrm{H}_{4} \mathrm{R}$ activation prevents the development of reperfusion injury in a model of ischemia-induced liver damage [41]. Hence, our work extends the knowledge of $\mathrm{H}_{4} \mathrm{R}$ activity and supports new perspectives on the use of $\mathrm{H}_{4} \mathrm{R}$ agonists in a pathological context. Moreover, microparticle-mediated delivery of histamine or $\mathrm{H}_{4} \mathrm{R}$ agonists might provide a new opportunity for the treatment of various CNS disorders accompanied by microglia-derived inflammation. Nevertheless, it should be noted that the majority of reports refer to the anti-inflammatory actions of $\mathrm{H}_{4} \mathrm{R}$ antagonists in conditions such as pruritus, dermatitis, airway inflammation and arthritis [8].

Cytokine signaling is a particularly relevant feature in the local development of the inflammatory reaction, but also in the recruitment of immune cells through the upregulation of adhesion molecules and induction of chemokines. In our study we evaluated the role of the proinflammatory cytokines IL- $1 \beta$ and TNF- $\alpha$ in histaminemodulated migration. We have previously described the involvement of IL-1 $\beta$ signaling in LPS-induced microglia migration in which we observed that blocking the IL-1 receptor led to the loss of the LPS pro-migratory effect [16]. However, IL-1 receptor blockade does not impair histamine-induced migration, suggesting the involvement of different migration mechanisms. Cells pre-treated with IL$1 \mathrm{ra}(150 \mathrm{ng} / \mathrm{ml})$ and incubated with histamine were still able to migrate, although not entirely similarly to histamine alone (meanHIS + IL-1ra $=148 \pm 5.8$ cells; meanHIS $=174.4 \pm 5.9$ cells, $n=3$; data not shown), suggesting that histamine does not require IL-1 $\beta$ signaling to induce migration, but affects its release, possibly to control a cytotoxic effect caused by the IL- $1 \beta$ release induced by a strong LPS inflammatory stimulus [16]. Interestingly, histamine per se does not modulate IL-1 $\beta$ release; however, it inhibited IL-1 $\beta$ release upon LPS challenge, an effect mimicked by $\mathrm{H}_{4} \mathrm{R}$ agonist. In organotypic slice cultures, which include more complex cellular interactions and different cell types (including neurons, astrocytes, oligodendrocytes and microglia), $\mathrm{H}_{4} \mathrm{R}$ blockade did not fully restore LPS-induced IL-1 $\beta$ release in the presence of histamine, suggesting the involvement of other receptors or different modulation mechanisms by other types of cells present in the slices. Our results suggest that in a healthy brain parenchyma, exogenous application of histamine would enhance the microglia surveillance, whereas, in an inflammatory context, histamine would restrain microglia motility while maintaining a putative anti-inflammatory profile.

Importantly, it has been reported that in IL-1 receptor 1 (IL-1R1) null mice microglia activation is abrogated when stab wounds are performed. The authors observed that in the absence of IL-1R1, almost no reactive or ameboid microglia are found, and leukocyte infiltration is very reduced. Also, in these knockout mice, the proinflammatory cytokine expression was decreased [42]. However, we did not observe TNF- $\alpha$ release upon histamine or histamine microparticles in both experimental models used.

Regarding TNF- $\alpha$ release, histamine has been described to inhibit LPS-stimulated TNF- $\alpha$ release by human monocytes, human and rat alveolar macrophages, and human peripheral blood mononuclear cells [43-45]. In the studies performed by Sirois and colleagues [44] and by Morichika and colleagues [45], the LPS concentration ranged from $1-5 \mathrm{ng} / \mathrm{ml}$, and the histamine concentration ranged from $10^{-4}-10^{-7} \mathrm{M}$; their co-administration inhibited LPS-induced TNF- $\alpha$ release. However, in the study developed by Rowe and colleagues [43], human alveolar macrophages and monocytes differed in their responses to histamine. Histamine $\left(10^{-5} \mathrm{M}\right)$ inhibited LPS-stimulated (500 ng/ $\mathrm{ml}$ ) TNF- $\alpha$ release by monocytes, but had no effect on alveolar macrophages. These results suggest that the inhibitory effect of histamine on LPS-induced TNF- $\alpha$ release may depend on the LPS concentration (we used $100 \mathrm{ng} / \mathrm{ml}$ ) and on cell type. Noteworthily, work performed by Desai and Thurmond [23] showed that histamine and LPS co-treatment potentiated IL-6 release by mast cells, although it had no effect on TNF- $\alpha$ release, suggesting that, depending on the stimulus, different cells may present specific patterns of response regarding cytokine release. Given the unique properties of the brain parenchyma microenvironment, it is reasonable to assume that although microglial cells share a great deal of similarity with monocytes/macrophages, they are endowed with a different range of signaling responses. 


\section{Conclusions}

Our results open promising new perspectives for the therapeutic use of histamine and histamine receptor agonists to treat or ameliorate inflammation-associated processes. Histamine has been perceived as a major inflammatory mediator in allergic responses. In accordance, we showed that histamine can trigger microglia motility per se, but not the release of the pro-inflammatory cytokines IL-1 $\beta$ and TNF- $\alpha$. Most importantly, we have now revealed new anti-inflammatory properties of histamine $\mathrm{H}_{4}$ receptor agonists that counteract LPSmediated inflammatory actions, namely motility/migration and IL- $1 \beta$ release by microglia/CNS invading macrophages. Therefore, the use of histamine-loaded microparticles (or ultimately, microparticles loaded with $\mathrm{H}_{4} \mathrm{R}$ agonists) could provide a rapid, more efficient and affordable approach in an inflammatory context.

\begin{abstract}
Abbreviations
ELISA: Enzyme-linked Immunosorbent Assay; $\mathrm{H}_{4} \mathrm{R}$ : Ristamine Receptor 4; IL-1ß: Interleukin-1beta; LPS: Lipopolysaccharide; MAPK: Mitogen-activated Protein Kinase; qPCR: quantitative Polymerase Chain Reaction; TLR4: Toll-like Receptor 4; RT: Room Temperature; TNF-a: Tumor Necrosis Factor-alpha.
\end{abstract}

\section{Competing interests}

This work is under patent protection (patent application no. 20111000054869).

\section{Acknowledgements}

The authors wish to thank Prof. Claudia Verderio from the CNR Institute of Neuroscience and Department of Medical Pharmacology, University of Milan, Italy, for her generous gift of the murine N9 microglial cell line and Prof. Paulo Santos from the Center for Neuroscience and Cell Biology, University of Coimbra, Portugal. This work was supported by FCT Portugal and FEDER, PTDC/SAU-NEU/104415/2008 and PTDC/SAU-NEU/101783/2008, grant no. 96542, from the Calouste Gulbenkian Foundation and L'Oréal-UNESCO Portugal for Women in Science, MIT-Portugal and PTDC/CTM/099659/2008.

\section{Author details}

${ }^{1}$ CNC - Center for Neuroscience and Cell Biology, University of Coimbra, Coimbra, Portugal. ' Laboratory of Pharmacology and Experimental Therapeutic, Faculty of Medicine, University of Coimbra, Coimbra, Portugal. ${ }^{3}$ Institute of Biomedical Research on Light and Image (IBILI), Faculty of Medicine, University of Coimbra, Coimbra, Portugal. ${ }^{4} \mathrm{CICS}-U B \mathrm{BI}$ - Health Sciences Research Center, University of Beira Interior, Covilhã, Portugal. ${ }^{5}$ Biocant, Centro de Inovação em Biotecnologia, Cantanhede, Portugal. ${ }^{6} \mathrm{CICS}-$ UBI - Health Sciences Research Center, Av. Infante D. Henrique, University of Beira Interior, Covilhã 6200-506, Portugal.

\section{Authors' contributions}

RF performed the scratch wound assays, cortex explants, real-time PCR studies, Western blotting, ELISA measurements for IL-1 $\beta$,

immunocytochemistry studies, statistical analysis and wrote the manuscript. TS participated in the scratch wound assays and cortex explants, real-time PCR studies and acquisition of confocal images. JG performed the ELISA measurements for TNF-a. GB performed the primary microglia cultures. LF developed the PLGA microparticles and participated in coordination of the study. FA participated in the project design, provided financial support and coordinated the study. LB conceived the study, participated in its design, performed primary microglial cultures and organotypic slice cultures, wrote the manuscript, provided financial support and coordinated the project. All authors read and approved the manuscript.
Received: 25 January 2012 Accepted: 8 May 2012

Published: 8 May 2012

\section{References}

1. Garden G, Möller T: Microglia biology in health and disease. $J$ Neuroimmune Pharmacol 2006, 1:127-137.

2. Block ML, Zecca L, Hong J-S: Microglia-mediated neurotoxicity: uncovering the molecular mechanisms. Nat Rev Neurol 2007, 8:57-69.

3. Rivest S: Molecular insights on the cerebral innate immune system. Brain Behav Immun 2003, 17:13-19.

4. Cohen J: The immunopathogenesis of sepsis. Nature 2002, 420:885-891.

5. Kinet JP: The high-affinity IgE receptor (Fc epsilon RI): from physiology to pathology. Annu Rev Immunol 1999, 17:931-972.

6. Katoh Y, Niimi M, Yamamoto Y, Kawamura T, Morimoto-Ishizuka T, Sawada $M$, Takemori $H$, Yamatodani A: Histamine production by cultured microglial cells of the mouse. Neurosci Lett 2001, 305:181-184.

7. Dy M, Schneider E: Histamine-cytokine connection in immunity and hematopoiesis. Cytokine Growth Factor Rev 2004, 15:393-410.

8. Zampeli $\mathrm{E}$, Tiligada $\mathrm{E}$ : The role of histamine $\mathrm{H} 4$ receptor in immune and inflammatory disorders. Br J Pharmacol 2009, 157:24-33.

9. de Esch IJ, Thurmond RL, Jongejan A, Leurs R: The histamine H4 receptor as a new therapeutic target for inflammation. Trends Pharmacol Sci 2005 26:462-469.

10. Ferreira R, Xapelli S, Santos T, Silva AP, Cristovao A, Cortes L, Malva JO: Neuropeptide $Y$ modulation of interleukin-1 beta (IL-1 $\beta$ )-induced nitric oxide production in microglia. J Biol Chem 2010, 285:41921-41934.

11. Saura J, Tusell JM, Serratosa J: High-yield isolation of murine microglia by mild trypsinization. Glia 2003, 44:183-189.

12. Ferreira LS, Gerecht S, Fuller J, Shieh HF, Vunjak-Novakovic G: Bioactive hydrogel scaffolds for controllable vascular differentiation of human embryonic stem cells. Biomaterials 2007, 28:2706-2717.

13. Bernardino L, Eiriz MF, Santos T, Xapelli S, Grade S, Rosa A, Cortes L, Ferreira $R$, Bragança J, Agasse $F$, et al: Histamine stimulates neurogenesis in the rodent subventricular zone. Stem Cells 2012, 30:773-784.

14. Valster A, Tran NL, Nakada M, Berens ME, Chan AY, Symons M: Cell migration and invasion assays. Methods 2005, 37:208-215.

15. Ferreira R, Santos T, Viegas M, Cortes L, Bernardino L, Vieira OV, Malva JO: Neuropeptide $Y$ inhibits interleukin-1beta-induced phagocytosis by microglial cells. J Neuroinflammation 2011, 8:169.

16. Ferreira R, Santos T, Cortes L, Cochaud S, Agasse F, Silva AP, Xapelli S, Malva JO: Neuropeptide $Y$ inhibits interleukin-1 beta (IL-1 $\beta$ )-induced microglia motility. J Neurochem 2012, 120:93-105.

17. Bustin S: Absolute quantification of mRNA using real-time reverse transcription polymerase chain reaction assays. J Mol Endocrinol 2000, 25:169-193

18. Strakhova MI, Nikkel AL, Manelli AM, Hsieh GC, Esbenshade TA, Brioni JD, Bitner RS: Localization of histamine $\mathrm{H} 4$ receptors in the central nervous system of human and rat. Brain Res 2009, 1250:41-48.

19. Connelly WM, Shenton FC, Lethbridge N, Leurs R, Waldvogel HJ, Faull RL, Lees G, Chazot PL: The histamine H4 receptor is functionally expressed on neurons in the mammalian CNS. Br J Pharmacol 2009, 157:55-63.

20. Vetvicka V, Hanikyrova M, Vetvickova J, Ross GD: Regulation of CR3 (CD11b/CD18)-dependent natural killer (NK) cell cytotoxicity by tumour target cell MHC class I molecules. Clin Exp Immunol 1999, 115:229-235.

21. Fletcher DA, Mullins RD: Cell mechanics and the cytoskeleton. Nature 2010, 463:485-492.

22. Parsons JT, Horwitz AR, Schwartz MA: Cell adhesion: integrating cytoskeletal dynamics and cellular tension. Nat Rev Mol Cell Biol 2010, 11:633-643.

23. Desai $P$, Thurmond RL: Histamine $H$ receptor activation enhances LPSinduced IL-6 production in mast cells via ERK and PI3K activation. Eur J Immunol 2011, 41:1764-1773.

24. Horvath RJ, DeLeo JA: Morphine enhances microglial migration through modulation of P2X4 receptor signaling. J Neurosci 2009, 29:998-1005.

25. Martin S, Vincent JP, Mazella J: Involvement of the neurotensin receptor-3 in the neurotensin-induced migration of human microglia. J Neurosci 2003, 23:1198-1205.

26. Hanisch UK, Kettenmann H: Microglia: active sensor and versatile effector cells in the normal and pathologic brain. Nat Neurosci 2007, 10:1387-1394. 
27. Haas HL, Sergeeva OA, Selbach O: Histamine in the nervous system. Physiol Rev 2008, 88:1183-1241.

28. Perry VH, Nicoll JAR, Holmes C: Microglia in neurodegenerative disease. Nat Rev Neurol 2010, 6:193-201.

29. Buckland KF, Williams TJ, Conroy DM: Histamine induces cytoskeletal changes in human eosinophils via the $\mathrm{H}(4)$ receptor. Br J Pharmacol 2003, 140:1117-1127.

30. Ridley AJ, Schwartz MA, Burridge K, Firtel RA, Ginsberg MH, Borisy G, Parsons JT, Horwitz AR: Cell migration: integrating signals from front to back. Science 2003, 302:1704-1709.

31. Nasu-Tada K, Koizumi S, Inoue K: Involvement of beta1 integrin in microglial chemotaxis and proliferation on fibronectin: different regulations by ADP through PKA. Glia 2005, 52:98-107.

32. Jin YJ, Park I, Hong IK, Byun HJ, Choi J, Kim YM, Lee H: Fibronectin and vitronectin induce AP-1-mediated matrix metalloproteinase-9 expression through integrin alpha(5)beta(1)/alpha(v)beta(3)-dependent Akt, ERK and JNK signaling pathways in human umbilical vein endothelial cells. Cell Signal 2011, 23:125-134.

33. Haque A, Jones GE: Cell motility assays. Cell Biol Toxicol 2008, 24:381-389.

34. Matsuo M, Sakurai H, Ueno Y, Ohtani O, Saiki I: Activation of MEK/ERK and PI3K/Akt pathways by fibronectin requires integrin alphav-mediated ADAM activity in hepatocellular carcinoma: a novel functional target for gefitinib. Canc Sci 2006, 97:155-162.

35. Wang HQ, Bai L, Shen BR, Yan ZQ, Jiang ZL: Coculture with endothelial cells enhances vascular smooth muscle cell adhesion and spreading via activation of beta1-integrin and phosphatidylinositol 3-kinase/Akt. Eur J Cell Biol 2007, 86:51-62.

36. Zhu H, Liu XW, Cai TY, Cao J, Tu CX, Lu W, He QJ, Yang B: Celastrol acts as a potent antimetastatic agent targeting beta 1 integrin and inhibiting cell-extracellular matrix adhesion, in part via the p38 mitogen-activated protein kinase pathway. J Pharmacol Exp Ther 2010, 334:489-499.

37. Furundzija V, Fritzsche J, Kaufmann J, Meyborg H, Fleck E, Kappert K, Stawowy P: IGF-1 increases macrophage motility via PKC/p38-dependent av $\beta$ v3-integrin inside-out signaling. Biochem Biophys Res Commun 2010, 394:786-791.

38. Smits RA, Lim HD, Hanzer A, Zuiderveld OP, Guaita E, Adami M, Coruzzi G, Leurs $\mathrm{R}$, de Esch IJ: Fragment based design of new $\mathrm{H} 4$ receptor-ligands with anti-inflammatory properties in vivo. J Med Chem 2008, 51:2457-2467.

39. Morgan RK, McAllister B, Cross L, Green DS, Kornfeld H, Center DM, Cruikshank WW: Histamine 4 receptor activation induces recruitment of FoxP3+ T cells and inhibits allergic asthma in a murine model. $J$ Immunol 2007, 178:8081-8089.

40. Osna N, Elliott K, Khan MM: Regulation of interleukin-10 secretion by histamine in TH2 cells and splenocytes. Int Immunopharmacol 2001, 1:85-96.

41. Adachi N, Liu K, Motoki A, Nishibori M, Arai T: Suppression of ischemia/ reperfusion liver injury by histamine $\mathrm{H} 4$ receptor stimulation in rats. Eur J Pharmacol 2006, 544:181-187.

42. Basu A, Krady JK, O'Malley M, Styren SD, DeKosky ST, Levison SW: The type 1 interleukin-1 receptor is essential for the efficient activation of microglia and the induction of multiple proinflammatory mediators in response to brain injury. J Neurosci 2002, 22:6071-6082.

43. Rowe J, Finlay-Jones JJ, Nicholas TE, Bowden J, Morton S, Hart PH: Inability of histamine to regulate TNF-alpha production by human alveolar macrophages. Am J Respir Cell Mol Biol 1997, 17:218-226.

44. Sirois J, Menard G, Moses AS, Bissonnette EY: Importance of histamine in the cytokine network in the lung through $\mathrm{H} 2$ and $\mathrm{H} 3$ receptors: stimulation of IL-10 production. J Immunol 2000, 164:2964-2970.

45. Morichika T, Takahashi HK, Iwagaki H, Yoshino T, Tamura R, Yokoyama M, Mori S, Akagi T, Nishibori M, Tanaka N: Histamine inhibits lipopolysaccharide-induced tumor necrosis factor-alpha production in an intercellular adhesion molecule-1- and B7.1-dependent manner. $J$ Pharmacol Exp Ther 2003, 304:624-633.

doi:10.1186/1742-2094-9-90

Cite this article as: Ferreira et al:: Histamine modulates microglia function. Journal of Neuroinflammation 2012 9:90.

\section{Submit your next manuscript to BioMed Central and take full advantage of:}

- Convenient online submission

- Thorough peer review

- No space constraints or color figure charges

- Immediate publication on acceptance

- Inclusion in PubMed, CAS, Scopus and Google Scholar

- Research which is freely available for redistribution

Submit your manuscript at www.biomedcentral.com/submit
() Biomed Central 